\title{
From Cadomian arc to Ordovician passive margin: geochemical records preserved in metasedimentary successions of the Orlica-Snieżnik Dome in SW Poland
}

\author{
Jacek Szczepański • Sławomir Ilnicki
}

Received: 24 June 2013 / Accepted: 20 December 2013 / Published online: 10 January 2014

(C) The Author(s) 2014. This article is published with open access at Springerlink.com

\begin{abstract}
The chemical composition of metamorphosed siliciclastic rocks in the Orlica-Śnieżnik Dome (Bohemian Massif) identifies the main sources for the Neoproterozoic [the Młynowiec Formation (MF)], Early Cambrian [the Stronie Formation (SF)] and Late Cambrian/Early Ordovician [the Goszów quartzites (GQ)] sediments. The MF developed from erosion of a Cadomian magmatic arc along the northern Gondwana margin. The variegated SF, with supra-subduction affinities, shows chemical characteristics pointing to erosion of the freshly exhumed Cadomian orogen and detritus deposition in the back-arc basin. The very different chemical features of the GQ indicate deposition in a basin sited on a passive continental margin. The explanation proposed for the observed changes in chemical composition involves three main stages: (1) The pre $~ 540$ Ma evolution of an active continental margin and related back-arc basin ceased with the collision and accretion of the magmatic arc to the Gondwana margin; (2) Early Cambrian rift to drift transition (540-500 Ma) and development of a depositional basin filled with detritus derived from remnants of the magmatic arc; (3) Peri-Gondwana break-up leading to the formation of shallow-water passive margin depositional basins filled with quartz-rich detritus resembling Early Ordovician Armorican quartzites known from other parts of the Variscan Belt.
\end{abstract}

J. Szczepański $(\bowtie)$

Faculty of Earth Science and Environmental Management, Institute of Geological Sciences, University of Wroclaw, Pl. Maksa Borna 9, 50-204 Wrocław, Poland e-mail: js@ing.uni.wroc.pl

\section{S. Ilnicki}

Faculty of Geology, Institute of Geochemistry, Mineralogy and Petrology, University of Warsaw, Al. Żwirki i Wigury 93, 02-089 Warsaw, Poland
Keywords Trace-element geochemistry of metasediments · Provenance - Variscan Belt . Sudetes $\cdot$ Cadomian orogeny $\cdot$ Early Palaeozoic

\section{Introduction}

Modern siliciclastic sediments deposited in basins related to different tectonic settings vary in petrography of framework grains. This variability depends not only on provenance (i.e., source-area lithologies) but also on the tectonic setting of the depositional basin (Potter 1978; Dickinson and Valloni 1980; Valloni and Maynard 1981). The petrographic composition of any original basin sediment, and the proportion of framework grains to matrix, may be modified or even destroyed by later processes such as diagenesis, metamorphism and deformation. Consequently, the reconstruction of the tectonic setting of a depositional basin may become a difficult or even impossible task, particularly where the original successions are metamorphosed. In such cases, the application of major- and trace-element geochemistry can be fruitful (Bhatia and Taylor 1981; Bhatia 1983, 1985; Bhatia and Crook 1986; Roser and Korsch 1988). However, some workers have argued that the use of major-element geochemistry can lead to erroneous conclusions even in the case of very young sediments deposited in basins of known tectonic setting (Armstrong-Altrin and Verma 2005). Therefore, high-field-strength elements (HFSE) are considered more reliable. The main advantage is their low solubility in aqueous fluid which allows undisturbed transfer from the source area to a depositional basin without any fractionation (Holland 1978; McLennan 1989; Bierlein 1995). Moreover, HFSE are considered virtually immobile during diagenesis (Girty et al. 1994) and metamorphism (McLennan and Taylor 1991; Bau 1991; Girty 
et al. 1993). Thus, study of their concentrations in even metamorphosed siliciclastic sediments can provide reliable information regarding detritus provenance and the tectonic setting of the depositional basin.

The European Variscan Belt developed in response to closure of the Rheic Ocean followed by assembly of Pangea (e.g., Murphy et al. 2009; Nance et al. 2010) resulting from collision between Gondwana and Laurussia (e.g., Matte 1991). In Europe, the internal part of the orogenic belt includes some rock complexes which contain Cadomian basement derived from an arc developed at the Gondwanan margin during latest Neoproterozoic (e.g., Fernandez-Suarez et al. 2003; Linnemann et al. 2008). This arc was later detached from the edge of Gondwana during Late Cambrian-Early Ordovician times and drifted northward, resulting in the opening of the Rheic Ocean (Linnemann et al. 2008; Murphy et al. 2009; Nance et al. 2010). Cadomian rock complexes exposed within the Variscan Belt are composed of Neoproterozoic basement intruded by latest Cambrian ca 540-480 Ma granitoids and covered by metamorphosed sediments of Cambrian to Ordovician age (e.g., Linnemann and Romer 2002; Pereira et al. 2006). A typical feature of this metasedimentary cover is the existence of a sedimentation gap related to the Cadomian orogenesis (the Cadomian unconformity) which affected at least the earliest Cambrian. These Cadomian rock complexes have been documented in the Variscan Belt from Spain and Portugal through France and Germany to Poland (e.g., Linnemann et al. 2008). Recently, the Cadomian volcano-sedimentary succession with the earliest Cambrian sedimentation gap has been recognized in the Orlica-Śnieżnik Dome (OSD) in the Sudetes (Mazur et al. 2012).

This paper focuses on the chemical composition of metasediments from the Młynowiec and the Stronie Formations (SFs), and of the Goszów quartzites (GQ) cropping out in the OSD (Fig. 1). The chemical compositions of metasediments from both parts of the OSD separated by the Nysa Kłodzka Graben are used to show their compositional similarities with Cadomian- and post-Cadomian sedimentary sequences elsewhere in the Variscan Belt of Europe. Our results demonstrate that both the Młynowiec and the Stronie Formations were derived by erosion of supra-subduction rock complexes. The older Młynowiec Formation (MF) most probably represents sedimentary infill of a backarc basin developed between the Cadomian arc and the Gondwana passive margin (PM). The younger SF deposited after closure of this basin represents detritus derived from freshly formed Cadomian rocks. Interestingly, the detritus was laid down within an oceanic domain-the Rheic Ocean developed in response to separation of the Cadomian (Avalonian terrane) from Gondwana. In contrast, the GQ correspond to sediments deposited on the Gondwanan PM after separation of Avalonia. The evolutionary scheme for the sedimentary basins and tectonic settings proposed for the OSD metasediments described in the present work is in agreement with the tectonic scenario suggested for the evolution of the Neoproterozoic to Ordovician volcano-sedimentary successions preserved in the Saxo-Thuringian in Germany, and the Ossa-Morena and Central Iberian Zones in Portugal and Spain (e.g., Pereira et al. 2006; Linnemann et al. 2008). Moreover, it corroborates current hypotheses for the formation of the Rheic Ocean (e.g., Arenas et al. 2007, Sánchez-García et al. 2008; Martinez et al. 2009).

\section{Geology of the study area}

The OSD, situated in the easternmost part of the Central Sudetes (Fig. 1), exposes amphibolite facies orthogneisses mantled by rocks of a volcano-sedimentary succession. Though the orthogneisses are of different varieties, of which the Gierałtów migmatitic gneisses and the Śnieżnik porphyritic gneisses are the most important are of different varieties, all are derived from the same granitic protolith dated at 520-490 Ma, interpreted as the time of intrusion (e.g., Turniak et al. 2000; Lange et al. 2002, 2005). The gneisses host small inliers of (U) HP granulites and eclogites (e.g., Bakun-Czubarow 1992; Kryza et al. 1996; Štípská et al. 2004). The Upper Cretaceous Nysa Kłodzka Graben serves to divide the OSD into the eastern Śnieżnik Massif (SM) and the western Bystrzyckie and Orlickie Mountains Massif (BOM). Recently, the OSD has been interpreted as a mantled gneiss dome formed in response to crustal-scale folding initiated during Variscan collision of the Saxo-Thuringia and Brunia terranes (Chopin et al. 2012). In this model, the OSD represents Saxo-Thuringian crust underthrust beneath the Teplá-Barrandian terrane (TB) and subsequently exhumed in front of the Brunia rigid butress.

The supra-crustal rocks cropping out in the OSD represent a volcano-sedimentary succession traditionally divided into the monotonous $\mathrm{MF}$ and the variegated SF and collectively labelled as the Młynowiec-Stronie Group (Don et al. 1990). The SF rests on a thin horizon of the GQ, separating it from the underlying monotonous MF (Fischer 1936; Don et al. 1990). According to Fischer (1936), the discontinuity between the MF and SF was intruded by the granitic precursor of the Śnieżnik orthogneiss, a view that has never been questioned. However, more modern models suggest that the Śnieżnik granite intruded the volcano-sedimentary succession along the pre-Variscan subhorizontal planar structure (e.g., Don et al. 1990, 2003; Chopin et al. 2012). The entire metasedimentary sequence is believed to form a continuous succession of either Neoproteorozic to Cambrian age (micropalaeontological evidence, e.g., Gunia 1974, 1989; Gunia and Wierzchołowski 


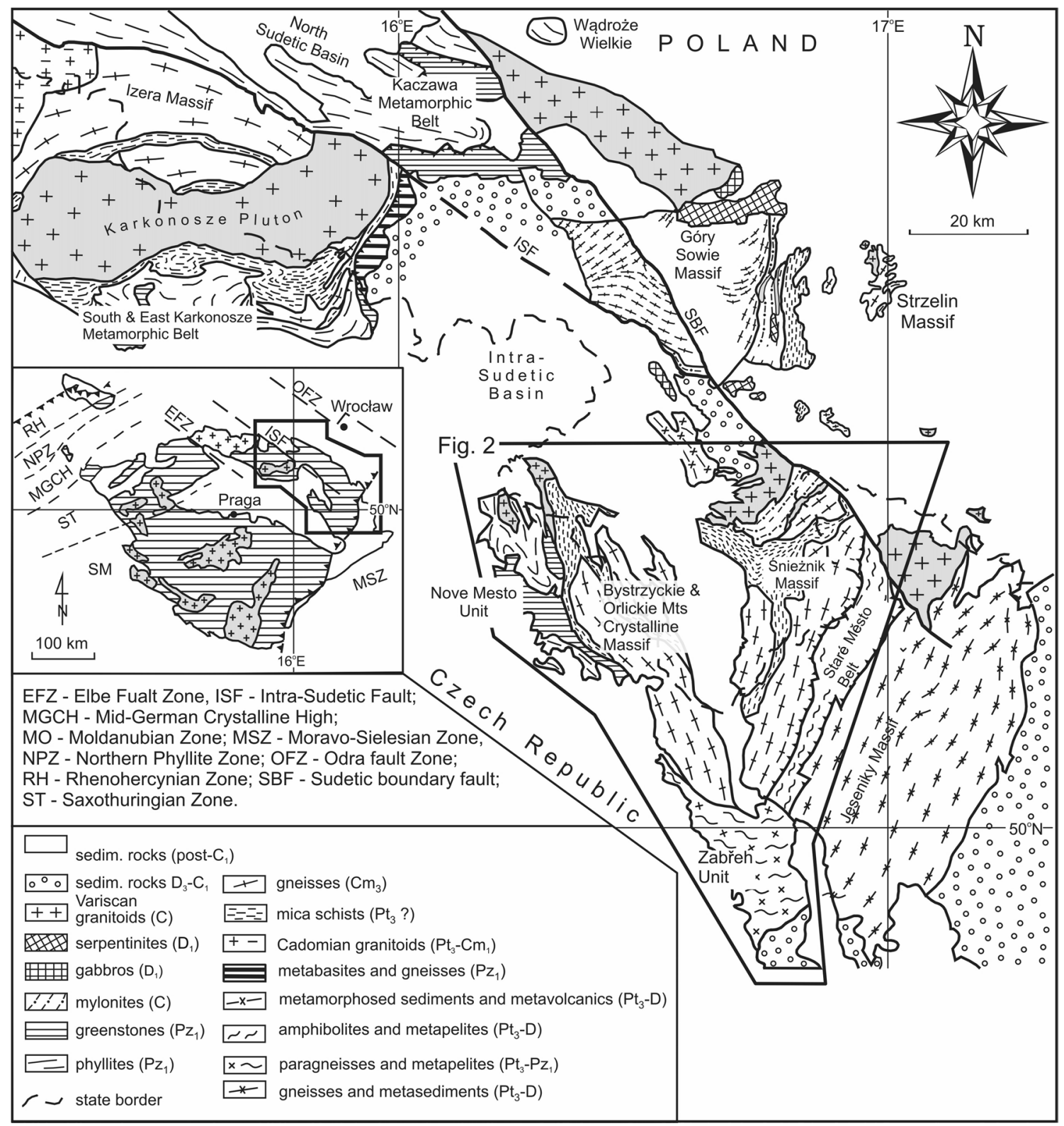

Fig. 1 Geological sketch map of the Sudetes after Mazur et al. (2005). The inset shows the location of the study area within the Bohemian Massif

1979) or of Cambrian to Ordovician age (Jastrzębski et al. 2010; detrital zircon geochronology). This view contradicts the suggestion that the MF and SF (including the basal GQ) are separated by a major unconformity (Fischer 1936; Don and Dowidar 1988; Don et al. 1990). Moreover, recent U-Pb SHRIMP data from detrital zircons indicate that the supra-crustal rocks record different maximum sedimentation ages. This allows the whole sequence to be interpreted as comprising distinct metasedimentary successions of different maximum deposition ages: Neoproterozoic for the MF, Early Cambrian for the SF and latest Cambrian Early Ordovician for the GQ (Mazur et al. 2012).
Thus, the volcano-sedimentary successions preserved in the OSD shows a very similar lithostratigraphic scheme to that observed in other parts of the Variscan Belt of Europe, e.g., the Saxo-Thuringian zone in Germany, and the OssaMorena and Central Iberian Zones in Spain and Portugal where relatively well-preserved fragments of Cadomian basement are covered by Cambrian and Ordovician successions (e.g., Linnemann et al. 2008; Pereira et al. 2006). This conclusion is reinforced by the occurrence of basic and felsic metavolcanics preserved in the volcano-sedimentary successions of the OSD. The chemical features of metabasalts in the western part of the OSD interfingering 
the SF resemble, in the main, basalts of E-MORB and N-MORB affinity with minor intercalations of alkaline metabasalts. This metavolcanic suite has been interpreted as formed during the transition from a back-arc to a riftedmargin setting during the final stages of the Cadomian orogeny and recording incipient early Palaeozoic rifting (Ilnicki et al. 2013). Interestingly, the chemistry of felsic volcanic dated at ca $500 \mathrm{Ma}$ (Murtezi and Fanning 2005) and interfingering the SF in the SM supports the interpretation that they originated in a supra-subduction environment related to back-arc spreading (Murtezi 2006). Finally, the isotopic evidence shows that the GQ cannot represent the base of the SF (Mazur et al. 2012). Taking into account the maximum depositional age of the quartzites and their petrographic features, these rocks resemble the Ordovician overstep sequence (Mazur et al. 2012) widespread in Central and Western Europe and deposited during the separation of Avalonia from Gondwana (Linnemann et al. 2008 and references therein).

For a long time, the age of the volcano-sedimentary successions in the BOM remained unknown. This hampered comparison of rock formations exposed in both eastern and western parts of the OSD, even though these show very similar lithology (Dumicz 1964; Szczepański 2010a). On the western part of the OSD in Poland, the volcano-sedimentary succession crops out in three tectonic units, namely, from NE to SW, the Młoty Unit, the Poręba Unit and the Niemojów Unit comprising orthogneiss bodies as well as the metavolcanic succession (Szczepański 2010a; inset in Fig. 2). The metasedimentary sequence in the Młoty Unit is dominated by monotonous paragneisses with rare inliers of metabasalts. The volcano-sedimentary succession in the Poręba Unit comprises variegated series composed mainly of mica schists intercalated with marbles, paragneisses, quartzites as well as felsic and basic metavolcanics. The latter shows in places well-preserved pillow structures (Szczepański 2010a; Ilnicki et al. 2013). Lithological similarities suggest that paragneisses of the Młoty Unit might be equivalents of the monotonous MF, while mica schists cropping out in the Poręba Unit may correspond to the variegated SF. Furthermore, U-Pb SHRIMP zircon ages obtained most recently for detrital zircons collected from mentioned metasedimentary successions cropping out in the BOM confirm these suggestions (Mazur et al. 2013). Unfortunately, the age of the quartzites in the BOM remains unknown. However, considering the numerous similarities between the three volcano-sedimentary successions exposed in both parts of the OSD, it seems reasonable to suggest that at least some of the quartzites in the BOM may be equivalents of the GQ preserved in the SM.

The tectonometamorphic evolution of the Polish part of the OSD involved between three and five tectonometamorphic events related mainly to the Variscan collisional episode and crustal-scale folding (e.g., Murtezi 2006; Jastrzębski 2009; Szczepański 2010a, 2011a, b; Skrzypek et al. 2011a, b; Chopin et al. 2012). Variscan metamorphism is partly characterized by a Barrovian zonal pattern with biotite-, garnet-, staurolite-, kyanite- and sillimanite zones developed (Opletal and Domečka 1983; Jastrzębski 2009; Szczepański 2010a; Chopin et al. 2012).

\section{Sampling and analytical methods}

Twenty-three representative rock samples were used for the geochemical study. Eight were collected in the western part of the OSD and fifteen in the eastern part of the OSD. They represent the paragneisses of the MF (6 samples), the mica schists and paragneisses of the SF (14) and the GQ (3; Fig. 2; Table 1).

The analyses were carried out at Acme Analytical Laboratories Ltd. (Vancouver, Canada). Major-element concentrations and concentrations of HFSE including rare-earth elements (REE) were determined using ICP-ES following lithium metaborate fusion and nitric acid digestion of $0.2 \mathrm{~g}$ samples. Loss on ignition (LOI) was measured by weight difference after ignition at $1,000{ }^{\circ} \mathrm{C}$. Detection limits are within $0.01 \%$ for major elements, between 0.1 and $0.5 \mathrm{ppm}$ for most trace elements, $1 \mathrm{ppm}$ for $\mathrm{Ba}, \mathrm{Sn}$ and $\mathrm{Zn}$ and $8 \mathrm{ppm}$ for $\mathrm{V}$. The analytical results are given in Table 2 . All diagrams were designed using the GCDKit software (Janoušek et al. 2006).

\section{Results}

\section{Petrography}

The rocks record varying degrees of metamorphism and deformation that resulted in complete recrystallization and the growth of new minerals. The primary framework mineralogy, matrix composition and relative proportions between framework grains and matrix have been destroyed. Consequently, conclusions based solely on petrography concerning original provenance and tectonic setting are tentative.

The mineral assemblages of the rocks are in part a function of their metamorphic history and, in part, of their primary sedimentological composition. Primary sedimentary textural relationships have been lost. Only modal abundance provide any mineralogical insight into what the primary rocks were. Table 3 shows modal compositions for selected OSD metasediments. Assuming that the metamorphic processes were isochemical, it is only possible to tentatively classify the paragneisses as originally mainly arkosic, the mica schists as largely lithic deposits and the quartzites as reflecting the metamorphism of quartz-rich 


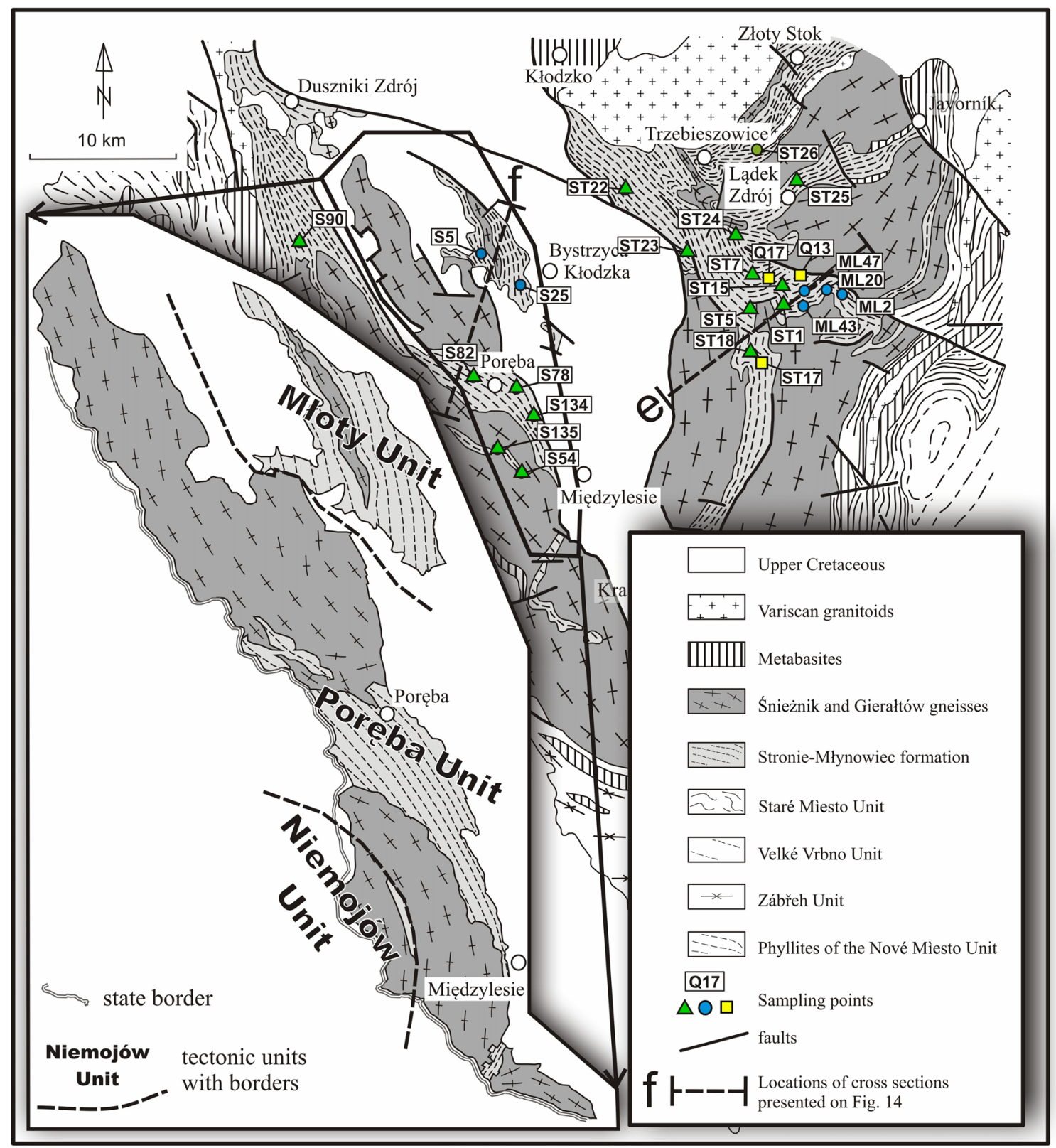

Fig. 2 Geological sketch map of the OSD after Fajst (1976) with sample locations marked. Inset shows tectonic units of the Bystrzyckie Mts according to Szczepański (2010a). Blue circles the MF, green triangles the SF, yellow boxes the GQ

sediments. It seems that high $\mathrm{Al}$ content in some of the analysed SF and MF rocks (Table 2) may suggest semipelitic protholit to these samples, what is documented also by the diagram from Fig. 4.

\section{Major elements}

The major oxide- and trace-element concentrations of the analysed OSD rocks are given in the Table 2. Contents of $\mathrm{SiO}_{2}$ and $\mathrm{Al}_{2} \mathrm{O}_{3}$ for rocks of the MF and $\mathrm{SF}$ are similar and show moderate variation in mean values yielding, respectively, $65.33 \pm 5.18$ and $16.38 \pm 2.46$ for the MF, and $63.55 \pm 5.94$ and $17.84 \pm 3.26$ for the SF. They have low $\mathrm{SiO}_{2} / \mathrm{Al}_{2} \mathrm{O}_{3}(4.09 \pm 0.86$ for the $\mathrm{MF}$ and $3.81 \pm 1.54$ for the SF) indicative of immaturity. In contrast, the GQ quartzites are characterized by considerably higher $\mathrm{SiO}_{2}$ $(93.17 \pm 1.17)$ and lower $\mathrm{Al}_{2} \mathrm{O}_{3}(4.14 \pm 1.25)$ concentrations, and high values of $\mathrm{SiO}_{2} / \mathrm{Al}_{2} \mathrm{O}_{3}(24.23 \pm 8.58)$ that reflect the high maturity of the Goszów rocks.

Compared to the upper continental crust (UCC), the MF and $\mathrm{SF}$ have similar $\mathrm{SiO}_{2}, \mathrm{Al}_{2} \mathrm{O}_{3}, \mathrm{Fe}_{2} \mathrm{O}_{3}, \mathrm{MgO}$ and $\mathrm{K}_{2} \mathrm{O}$ abundances, variable amounts of $\mathrm{MnO}$ but are slightly 
Table 1 Sample locations and GPS coordinates in World Geodetic System 84 (WGS84)

\begin{tabular}{llll}
\hline Sample & Position & & $\begin{array}{l}\text { Metasedimentary } \\
\text { succession }\end{array}$ \\
\cline { 2 - 3 } & $\mathrm{N}$ & $\mathrm{E}$ & \\
\hline St 017a & $50^{\circ} 12^{\prime} 11.8^{\prime \prime}$ & $16^{\circ} 50^{\prime} 19.0^{\prime \prime}$ & $\mathrm{GQ}$ \\
Q13 & $50^{\circ} 17^{\prime} 07.4^{\prime \prime}$ & $16^{\circ} 53^{\prime} 32.5^{\prime \prime}$ & GQ \\
Q17 & $50^{\circ} 16^{\prime} 17.2^{\prime \prime}$ & $16^{\circ} 50^{\prime} 36.5^{\prime \prime}$ & GQ \\
s25 & $50^{\circ} 17^{\prime} 09.0^{\prime \prime}$ & $16^{\circ} 36^{\prime} 07.1^{\prime \prime}$ & MF \\
s5 & $50^{\circ} 17^{\prime} 52.8^{\prime \prime}$ & $16^{\circ} 33^{\prime} 00.0^{\prime \prime}$ & MF \\
ML 20 & $50^{\circ} 16^{\prime} 34.1^{\prime \prime}$ & $16^{\circ} 55^{\prime} 02.3^{\prime \prime}$ & MF \\
ML 43 & $50^{\circ} 14^{\prime} 22.5^{\prime \prime}$ & $16^{\circ} 53^{\prime} 38.9^{\prime \prime}$ & MF \\
ML 47 & $50^{\circ} 16^{\prime} 29.1^{\prime \prime}$ & $16^{\circ} 53^{\prime} 18.4^{\prime \prime}$ & MF \\
ML 02 & $50^{\circ} 15^{\prime} 42.2^{\prime \prime}$ & $16^{\circ} 56^{\prime} 37.0^{\prime \prime}$ & MF \\
s78B & $50^{\circ} 13^{\prime} 11.6^{\prime \prime}$ & $16^{\circ} 35^{\prime} 43.6^{\prime \prime}$ & SF \\
s134 & $50^{\circ} 11^{\prime} 43.0^{\prime \prime}$ & $16^{\circ} 37^{\prime} 02.4^{\prime \prime}$ & SF \\
s82 & $50^{\circ} 13^{\prime} 27.6^{\prime \prime}$ & $16^{\circ} 34^{\prime} 03.0^{\prime \prime}$ & SF \\
s135 & $50^{\circ} 10^{\prime} 46.7^{\prime \prime}$ & $16^{\circ} 34^{\prime} 00.3^{\prime \prime}$ & SF \\
St 1 & $50^{\circ} 14^{\prime} 11.9^{\prime \prime}$ & $16^{\circ} 51^{\prime} 51.6^{\prime \prime}$ & SF \\
St 5 & $50^{\circ} 14^{\prime} 09.5^{\prime \prime}$ & $16^{\circ} 50^{\prime} 07.3^{\prime \prime}$ & SF \\
St 15 & $50^{\circ} 16^{\prime} 13.1^{\prime \prime}$ & $16^{\circ} 51^{\prime} 42.1^{\prime \prime}$ & SF \\
St 18 & $50^{\circ} 12^{\prime} 29.0^{\prime \prime}$ & $16^{\circ} 49^{\prime} 35.8^{\prime \prime}$ & SF \\
s54 & $50^{\circ} 10^{\prime} 02.4^{\prime \prime}$ & $16^{\circ} 35^{\prime} 55.3^{\prime \prime}$ & SF \\
s90 & $50^{\circ} 20^{\prime} 04.6^{\prime \prime}$ & $16^{\circ} 23^{\prime} 23.8^{\prime \prime}$ & SF \\
St 22 & $50^{\circ} 21^{\prime} 24.6^{\prime \prime}$ & $16^{\circ} 40^{\prime} 54.6^{\prime \prime}$ & SF \\
St 23 & $50^{\circ} 18^{\prime} 44.1^{\prime \prime}$ & $16^{\circ} 45^{\prime} 37.6^{\prime \prime}$ & SF \\
St 24 & $50^{\circ} 19^{\prime} 39.1^{\prime \prime}$ & $16^{\circ} 49^{\prime} 27.4^{\prime \prime}$ & SF \\
St 26 & $50^{\circ} 23^{\prime} 25.2^{\prime \prime}$ & $16^{\circ} 50^{\prime} 43.2^{\prime \prime}$ & SF \\
\hline
\end{tabular}

enriched in $\mathrm{TiO}_{2}$ and depleted in $\mathrm{CaO}, \mathrm{Na}_{2} \mathrm{O}$ and $\mathrm{P}_{2} \mathrm{O}_{5}$ (Fig. 3). The GQ clearly depart from this picture in having lower abundance of all major elements, excepting $\mathrm{SiO}_{2}$. The GQ are also distinguished by a pronounced depletion in $\mathrm{CaO}$ and $\mathrm{Na}_{2} \mathrm{O}$ - much greater than that characterizing the other rocks analysed. The low $\mathrm{CaO}$ and $\mathrm{Na}_{2} \mathrm{O}$ concentrations may reflect chemical weathering in the source area or partial removal during metamorphism. This is confirmed by weak $(<0.58)$ correlation coefficients of $\mathrm{CaO}\left(-0.09_{[\mathrm{MF}+\mathrm{SF}}, 0.11_{[\mathrm{GQ}]}\right), \mathrm{Na}_{2} \mathrm{O}\left(0.54_{[\mathrm{MF}+\mathrm{SF}]}\right)$ and $\mathrm{K}_{2} \mathrm{O}\left(0.58_{[\mathrm{MF}+\mathrm{SF}]}, 0.11_{[\mathrm{GQ}]}\right)$ with $\mathrm{Al}_{2} \mathrm{O}_{3}$ for all age groups. Slightly higher concentrations of $\mathrm{TiO}_{2}$ relative to the UCC (Fig. 3) for most of the analysed rocks are probably due to higher heavy-mineral contents, mainly rutile and ilmenite.

In discriminating between mature and immature sediments, frequently used parameters are $\mathrm{SiO}_{2} / \mathrm{Al}_{2} \mathrm{O}_{3}$ and $\mathrm{Fe}_{2} \mathrm{O}_{3} / \mathrm{K}_{2} \mathrm{O}$ (Potter 1978; Herron 1988). $\mathrm{SiO}_{2} / \mathrm{Al}_{2} \mathrm{O}_{3}$ allows the abundance of quartz and feldspar relative to clay minerals to be assessed because of the lower $\mathrm{SiO}_{2} / \mathrm{Al}_{2} \mathrm{O}_{3}$ of the latter. $\mathrm{Fe}_{2} \mathrm{O}_{3} / \mathrm{K}_{2} \mathrm{O}$ serves as a gauge of mineral stability and is also believed to be a good measure of feldspar content. These parameters were used to classify the OSD rocks in
Fig. 4 (diagram from Herron 1988). Most of the MF and SF rocks plot in the field of shales and wackes, indicating high mica or clay protolith contents. One SF sample (st24), departing slightly from this pattern, is located within the litharenite field. In contrast, GQ samples of the GQ fall within the subarkose field, suggesting relatively high $\mathrm{Al}_{2} \mathrm{O}_{3}$ concentrations and, probably, high clay/mica contents. Moreover, the Herron diagram indicates that the rocks of the MF and SF are similar to the Neoproterozoic and Cambrian siliciclastic sediments of the Saxo-Thuringian Zone and that the GQ show a chemical affinity with the quartzrich sandstones from Saxo-Thuringian Zone (Linnemann and Romer, 2002; Fig. 4).

Trace elements

The REE patterns of the GQ differ systematically from those of the Młynowiec- and SFs (Fig. 5a-c). The GQ show $\mathrm{Eu} / \mathrm{Eu}^{*}$ anomalies in the narrow range $0.42-0.61$, (Table 2), LREE enrichment $(\mathrm{La} / \mathrm{Yb})_{\mathrm{CN}}=7.18-10.48$ and slightly inclined HREE patterns $(\mathrm{Gd} / \mathrm{Yb})_{\mathrm{CN}}=1.2-1.84$ where $\mathrm{CN}$ stands for chondrite-normalized values. In contrast, both the MF and SF rocks show strikingly different and variable Eu/Eu* anomalies in the range 0.50-0.85, LREE enrichment $(\mathrm{La} / \mathrm{Yb})_{\mathrm{CN}}=4.94-14.79$ and flat to slightly negative HREE patterns $(\mathrm{Gd} / \mathrm{Yb})_{\mathrm{CN}}=0.92-2.27$. The chemical compositions of rocks of the MF and SF are almost identical to those of metasediments from the Saxo-Thuringian Zone (Fig. 5a, b). However, the GQ rocks are characterized by lower abundance of all REE elements compared to their equivalents in the Saxo-Thuringian Zone-a difference that may reflect higher mica contents or additional mineral carriers of trace elements in the latter.

Abundance of most trace elements, including REE, in the MF and SF are similar to those of the UCC (Fig. 6ab). The rocks of the monotonous MF are characterized by distinct negative $\mathrm{Sr}$ and $\mathrm{Nb}$ anomalies, enrichment in $\mathrm{Cs}, \mathrm{Rb}$ and $\mathrm{Cr}$ and variable but generally higher amount of Sc, Y and Ni (Fig. 6a). Two samples (s25 and ML43) show slight depletion in LREE relative to the UCC. The $\mathrm{SF}$ rocks are chemically more varied and show negative $\mathrm{Sr}$ and $\mathrm{Nb}$ anomalies and distinct positive $\mathrm{Cs}$ anomalies (Fig. 6b). The remaining trace elements show variable but generally higher concentrations yielding up to $2.2 \times$ UCC. Sample st 24 shows a somewhat different pattern; it shows depletion in all analysed trace elements compared to the UCC (Fig. 6b). In this last case, the depletion may reflect the low abundance of micas. In contrast, the GQ rocks show very low concentrations of all the trace elements relative to the UCC (Fig. 6c). Furthermore, the chemical composition of these rocks is characterized by strong $\mathrm{Sr}, \mathrm{Nb}$ and $\mathrm{Sc}$ negative anomalies, and positive $\mathrm{Zr}$ and $\mathrm{Hf}$ anomalies as is well seen in samples Q13 and 


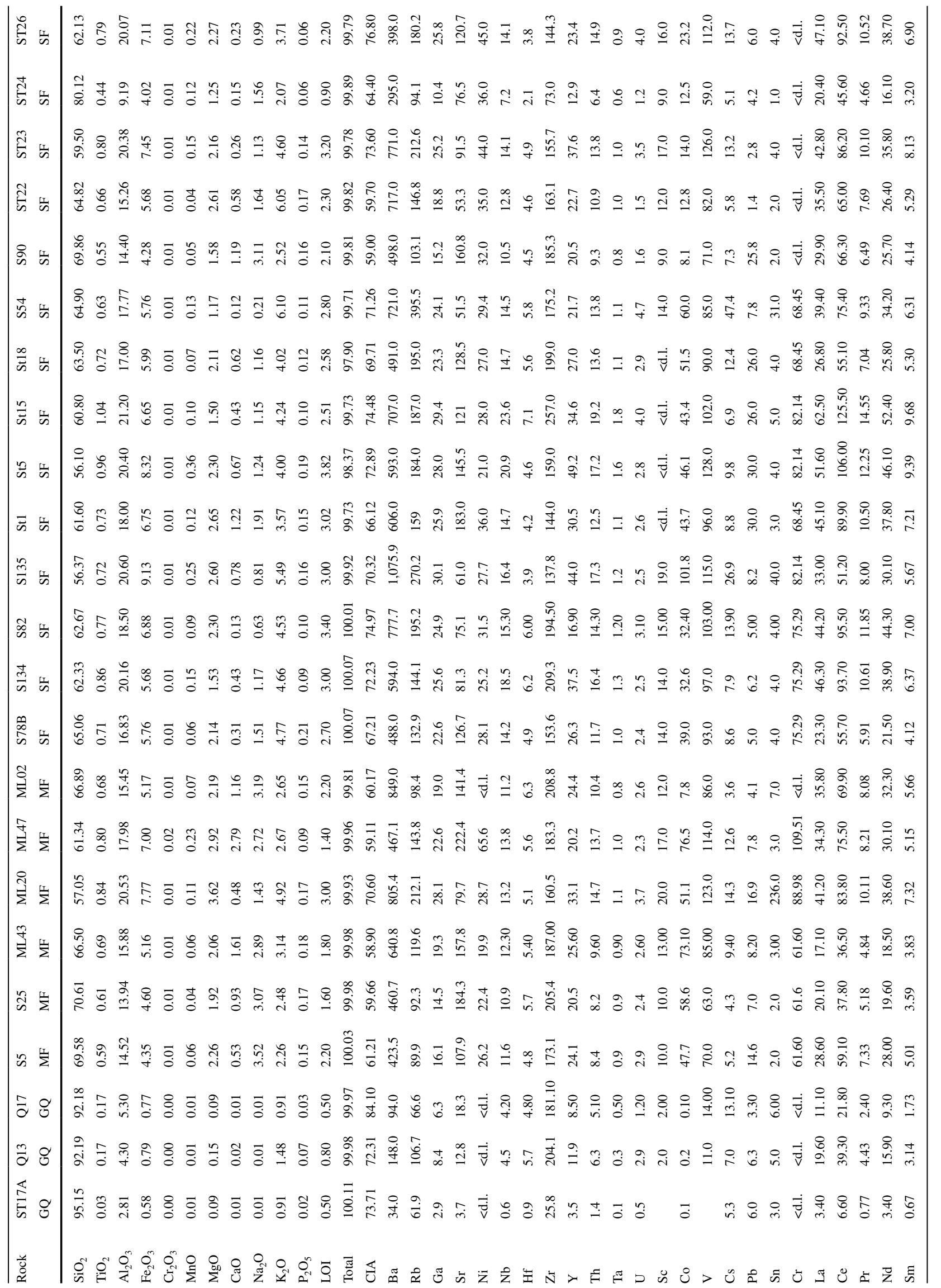




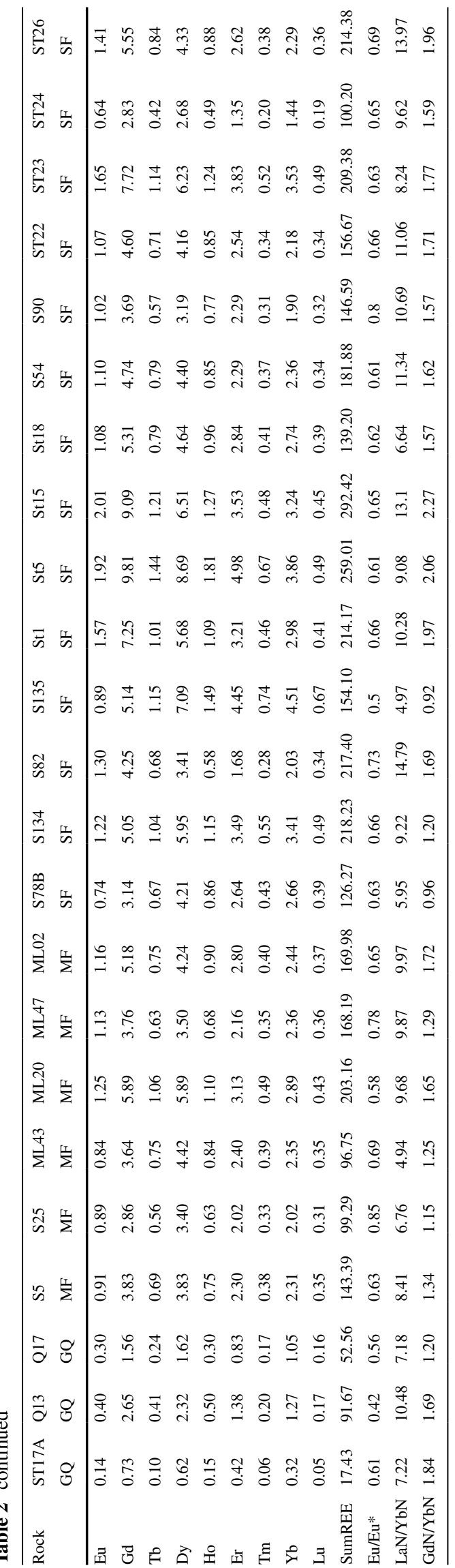

Q17. However, sample ST17 does not show positive Zr and $\mathrm{Hf}$ anomalies. As the REE patterns show (Figs. 5a, b, $6 \mathrm{a}, \mathrm{b})$, the rocks of the MF and SF have similar compositions to the Saxo-Thuringian Zone metasediments of similar age (Linnemann and Romer 2002). In contrast, the GQ are characterized by lower trace-element abundance when compared to the Ordovician quartz-rich rocks of the Saxo-Thuringian Zone (Linnemann and Romer 2002).

\section{Discussion}

Factors affecting bulk-rock chemistry

The chemical compositions of metamorphosed siliciclastic sediments mainly reflect that of the original sediments and their sources, and the tectonic setting of deposition. However, compositions may be altered by secondary processes such as metamorphism, chemical weathering and sedimentary recycling and sorting. Thus, it is necessary to evaluate the influence of each of these factors before addressing the provenance of the sediments and the tectonic setting of their deposition.

\section{Influence of metamorphism}

The OSD metasediments underwent green schist to amphibolite facies metamorphism that potentially affected concentrations of major- and trace elements. For this reason, samples containing veins and attesting to remobilization were avoided. Several lines of evidence argue against largescale element remobilization of particular trace elements. The MF and SF rocks show uniform and fairly smooth REE and trace-element patterns irrespective of the temperature of the recorded metamorphism (Figs 5a-c, 6a-c) - a feature not to be expected if any significant remobilization had taken place (Yang 1998). The large-ion lithophile elements (e.g., Na, K) in particular are most likely to have been affected by the metamorphic processes. However, any large-scale remobilization of REEs, $\mathrm{Th}, \mathrm{Zr}, \mathrm{Sc}, \mathrm{Cr}$ and $\mathrm{Co}$ seems unlikely.

Influence of weathering

The influence of weathering on the chemical composition of sediments is commonly evaluated using the chemical index of alteration, continental island arc (CIA), which is regarded as reflecting the progressive alteration of feldspars to clay minerals (Nesbitt and Young 1982). These workers proposed that CIA values for Phanerozoic shales normally range from 70 to 75 , suggesting moderate chemical weathering related to the formation of muscovite, illite and 
Table 3 Modal composition (in vol\%) of selected examined samples of metasediments from the OSD

Fig. 3 Upper continental crust-normalized major-element pattern for OSD metasediments. Normalization factors after Taylor and McLennan (1995)

\begin{tabular}{llllllll}
\hline Sample & Quartz & Feldspar & Micas & Garnet & Staurolite & Acc. min & Total \\
\hline s5 & 22.96 & 48.96 & 24.86 & 2.66 & 0.00 & 0.57 & 100.0 \\
s25 & 25.60 & 43.45 & 30.36 & 0.40 & 0.00 & 0.20 & 100.0 \\
s45A & 19.04 & 47.12 & 29.04 & 0.00 & 1.15 & 3.65 & 100.0 \\
s54 & 61.02 & 0.00 & 38.62 & 0.00 & 0.36 & 0.00 & 100.0 \\
s78B & 31.32 & 20.46 & 47.15 & 0.00 & 0.00 & 1.07 & 100.0 \\
s82 & 33.64 & 0.55 & 62.48 & 3.14 & 0.00 & 0.18 & 100.0 \\
s134 & 27.51 & 3.04 & 59.58 & 7.59 & 0.95 & 1.33 & 100.0 \\
s135 & 28.34 & 7.58 & 54.29 & 8.78 & 0.00 & 1.00 & 100.0 \\
st22 & 52.25 & 0.56 & 44.38 & 0.00 & 0.00 & 2.81 & 100.0 \\
st23 & 31.85 & 14.07 & 47.41 & 0.74 & 0.00 & 5.93 & 100.0 \\
ML47 & 36.23 & 21.26 & 37.09 & 4.99 & 0.00 & 0.43 & 100.0 \\
ML43 & 26.10 & 27.31 & 41.77 & 4.42 & 0.00 & 0.4 & 100.0 \\
\hline
\end{tabular}

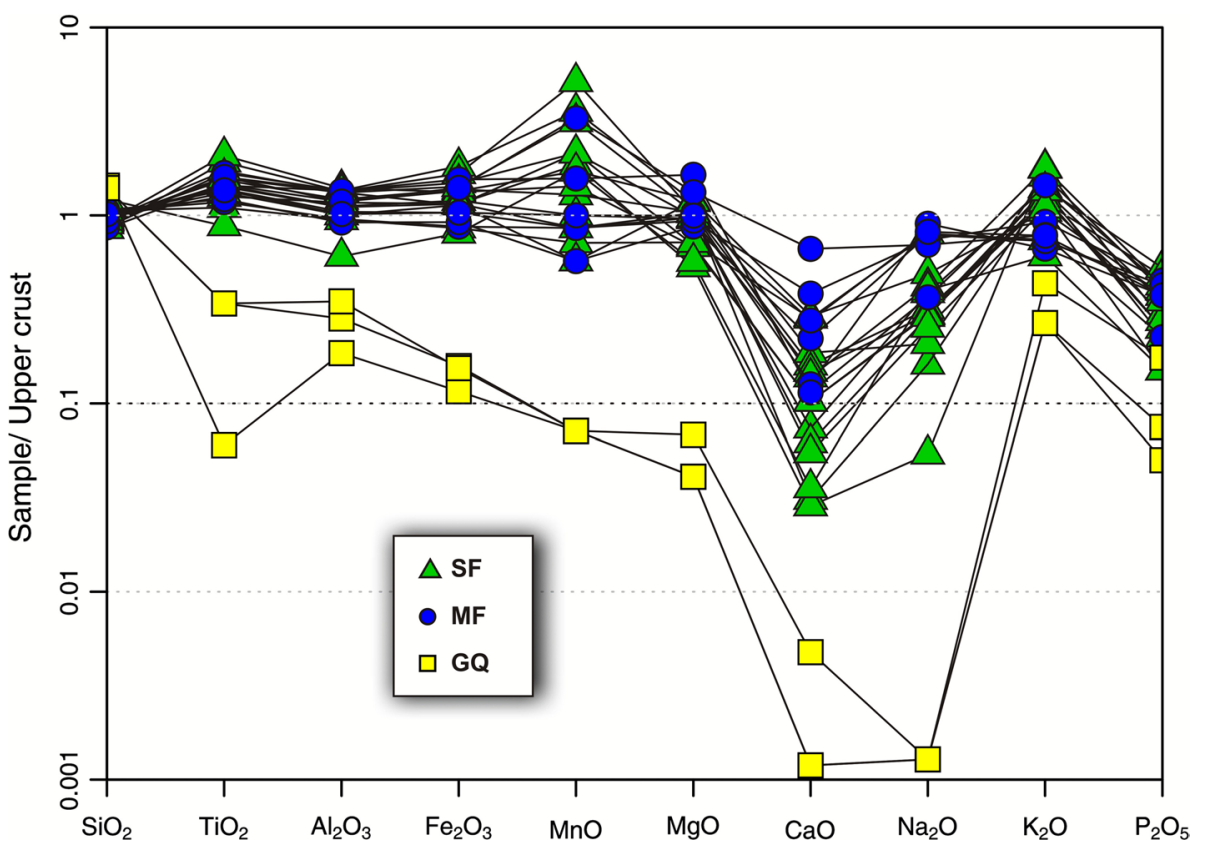

Fig. 4 Chemical classification scheme for OSD metasediments (after Herron 1988). Grey fields-chemical diversity of Neoproteorozic and Cambrian sediments as well as of Ordovician sandstones within the Saxothuringian Zone (after Linnemann and Romer 2002). GQ- the Goszów quartzites, MF-the Młynowiec Formation, SF-the Stronie Formation

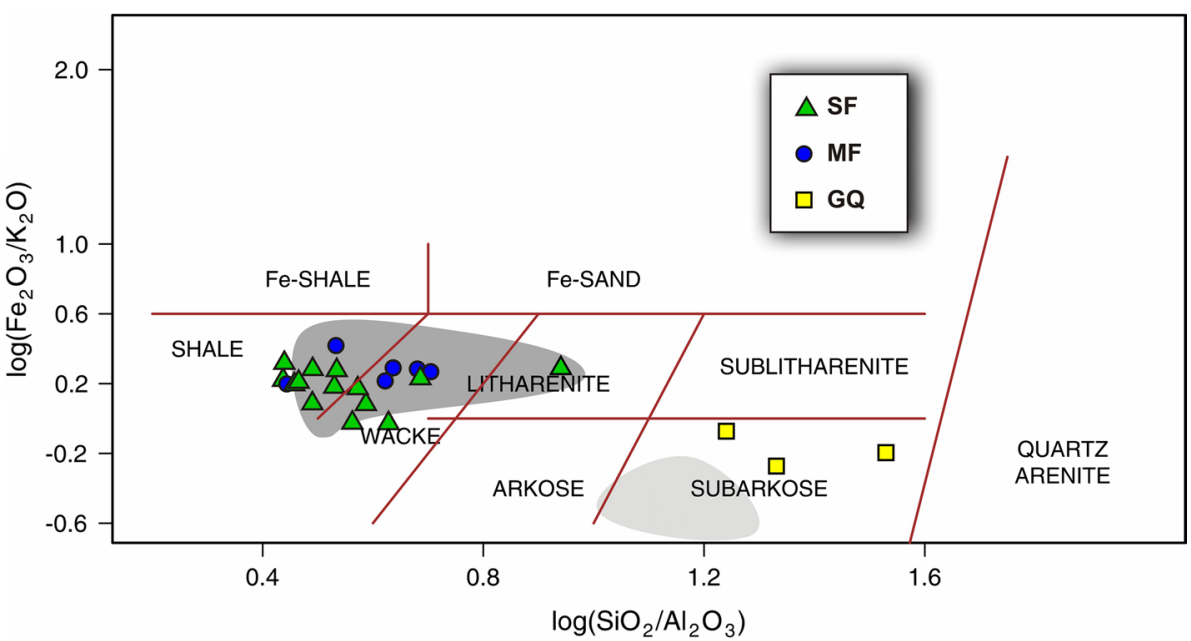



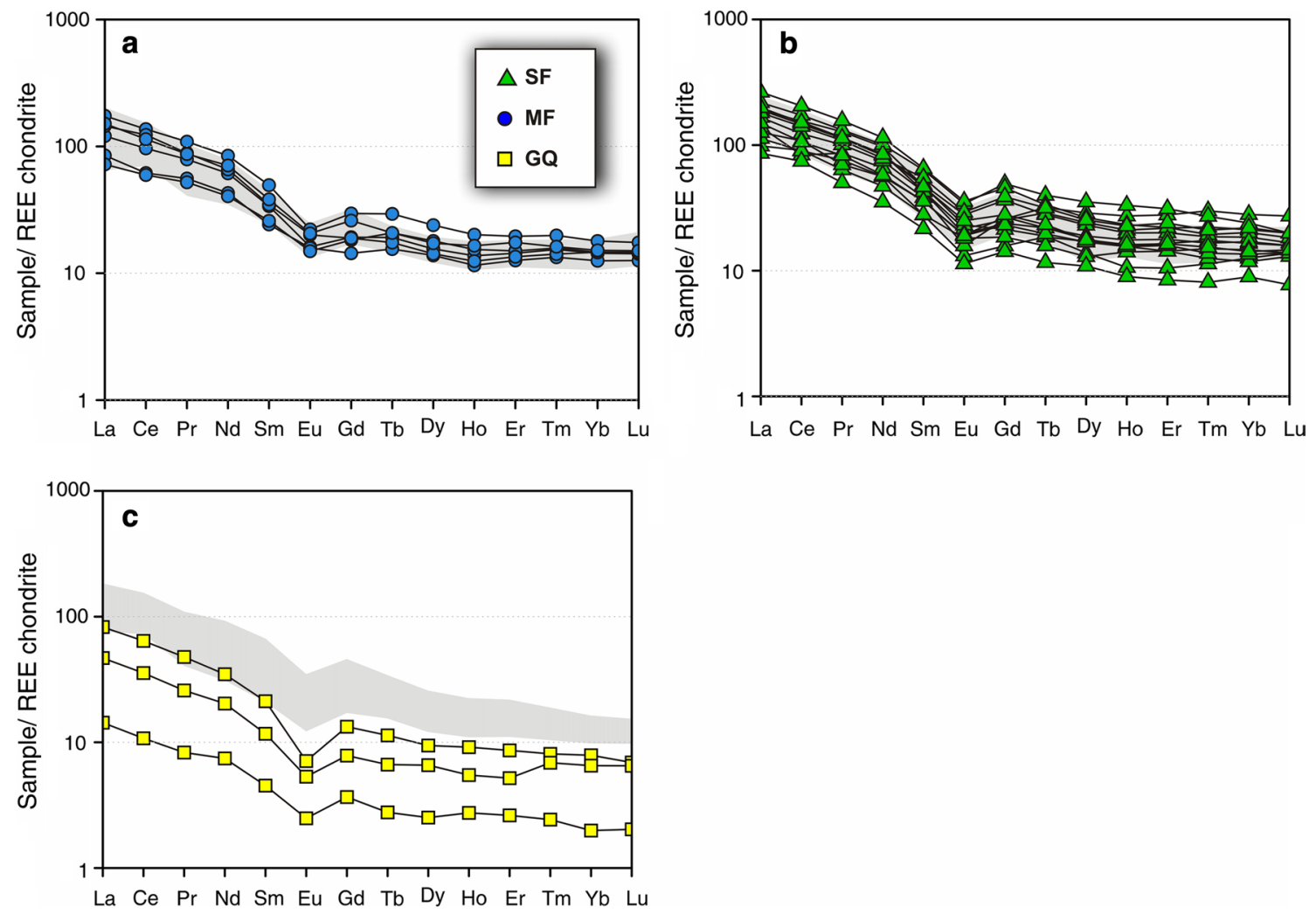

Fig. 5 Chondrite-normalized REE pattern for OSD metasediments. a Młynowiec Formation, b Stronie Formation, c Goszów quartzites. Normalization factors after Sun and McDonough (1989). Grey fields as in Fig. 4

smectite. A CIA value of $\sim 100$ is taken to indicate intense weathering leading to the growth of clay minerals such as kaolinite.

Unfortunately, as the CIA index employs elements regarded as mobile during metamorphism, conclusions based on the index must be treated with caution. Values of the CIA index for the OSD rocks fall in the range 59-84 with a mean of $68 \pm 7$ (Table 2). The GQ rocks are characterized by higher CIA values (72-84) than the remainder of the analysed rocks (59-77; Table 2). Compared to the average CIA values for shales (70-75; Taylor and McLennan 1985) and for fresh granitoids (45-55; Nesbitt and Young 1982), the protolith sediments of the paragneisses and schists show slight-to-moderate weathering and, those of the GQ, a relatively high degree of weathering. As observed on the ternary plots $\mathrm{A}-\mathrm{CN}-\mathrm{K}\left(\mathrm{Al}_{2} \mathrm{O}_{3}-\mathrm{CaO}+\mathrm{Na}_{2} \mathrm{O}-\right.$ $\left.\mathrm{K}_{2} \mathrm{O}\right)$ and $\mathrm{A}-\mathrm{CNK}-\mathrm{FM}\left(\mathrm{Al}_{2} \mathrm{O}_{3}-\mathrm{CaO}+\mathrm{Na}_{2} \mathrm{O}+\mathrm{K}_{2} \mathrm{O}-\right.$ $\mathrm{FeO}+\mathrm{MgO}$ ) proposed by Nesbitt and Young (1984) and Nesbitt and Young (1989), the OSD rocks show a marked loss in $\mathrm{Na}_{2} \mathrm{O}, \mathrm{K}_{2} \mathrm{O}$ and $\mathrm{CaO}$; the data define a trend typical for the weathering of acid magmatic rocks (Fig. 7a). A minor shift towards the FM apex (Fig. 7b) may indicate the influence of a secondary process, possibly sedimentary, which led to concentration of heavy minerals such as ilmenite.
Relative to $\mathrm{Th}, \mathrm{U}$ is easily mobilized during weathering and sedimentary recycling, resulting in an increase in $\mathrm{Th} / \mathrm{U}$. Although highly reduced sedimentary environments can be enriched in $\mathrm{U}$ and show low $\mathrm{Th} / \mathrm{U}$ ratios, the weathering process favours the oxidation of insoluble $\mathrm{U}^{4+}$ to soluble $\mathrm{U}^{6+}$ with subsequent loss of $\mathrm{U}$ and elevation of $\mathrm{Th} / \mathrm{U}$ (McLennan and Taylor 1980, 1991; McLennan et al. 1990). The Th/U values of all the OSD metasediments range from ca 2.2-7.3, and they follow the normal weathering trend (Fig. 8a). On average, the SF rocks are characterized by a mean $\mathrm{Th} / \mathrm{U}$ $(5.17 \pm 1.25)$ higher than that typical for the UCC $(\sim 3.8$; Taylor and McLennan 1985). However, the MF paragneisses show a mean $\mathrm{Th} / \mathrm{U}$ of $3.99 \pm 1.05$ which is close to the UCC value. Consequently, it is likely that the protolith of these rocks was derived from rather weakly weathered source rocks. The GQ have a Th/U 3.8 or slightly below, indicating a relatively minor degree of weathering - at variance with conclusions to be drawn from Fig. 7a. However, assessment of the degree of weathering based on Th and $\mathrm{U}$ seems more reliable than that based on $\mathrm{Ca}, \mathrm{Na}$ and $\mathrm{K}$ in these rocks.

The quartz dilution effect

The potential roles of zircon, allanite and monazite merit consideration (McLennan 1989) as these minerals were 

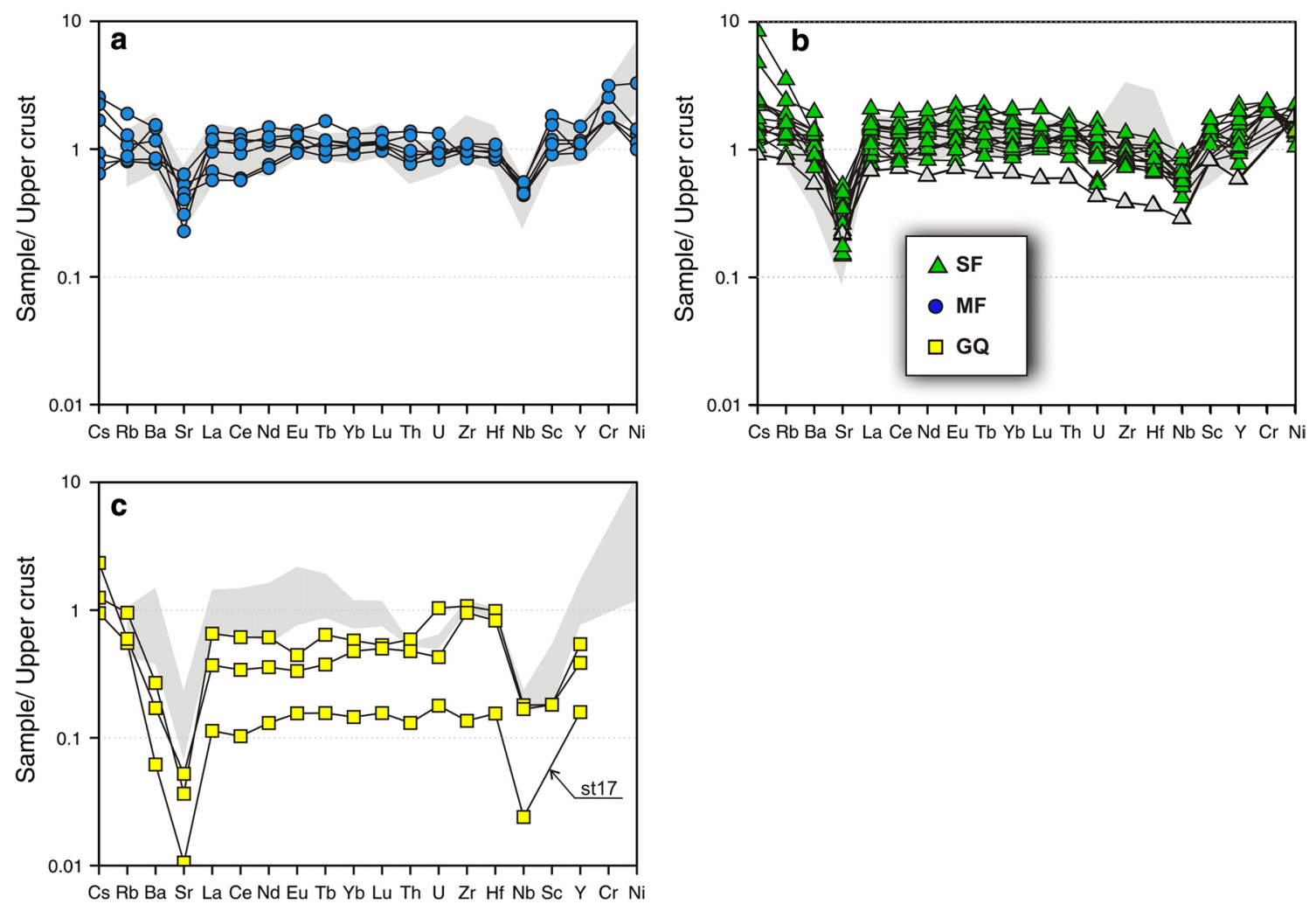

Fig. 6 Upper continental crust-normalized trace-element pattern for OSD metasediments. a Młynowiec Formation, b Stronie Formation, c Goszów quartzites. Normalization factors after Taylor and McLennan (1985). Grey triangles sample st24. Grey fields as in Fig. 4

reported from the OSD rocks (Jastrzębski et al. 2010; Szczepański 2010a; Mazur et al. 2012). Zircon abundance in sediments can be reflected by values of $\mathrm{Th} / \mathrm{Sc}$ and $\mathrm{Zr} /$ Sc (Fig. 8b; McLennan et al. 1993). Analyses reveal variable values of $\mathrm{Th} / \mathrm{Sc}$ ranging from 0.71 to 3.15 . The highest values (2.55-3.15), characteristic of the GQ, presumably reflect high zircon accumulation. Consequently, these quartzites are located on Fig. 8b along the line typical for deposits dominated by sediment recycling and zircon enrichment due to hydraulic sorting. The rest show $\mathrm{Th} / \mathrm{Sc}$ values ranging from 0.71 to 1.17 , indicating lesser degrees of zircon accumulation. However, as zircon preferentially incorporates HREE relative to LREE, zircon accumulation should lead to HREE enrichment and a decrease in $(\mathrm{La} / \mathrm{Yb})_{\mathrm{CN}}$. Such a trend is not evident in the studied samples (Fig. 9). Thus, with the exception of the GQ, it is possible that the chemical composition of the OSD rocks was mainly controlled by the sedimentary basin tectonic setting rather than by the secondary sorting and reworking of older deposits. The GQ have the chemical features of sediments typical of a PM.

The very low concentrations of most trace elements in the GQ together with the relatively high concentrations of $\mathrm{Zr}$ and $\mathrm{Hf}$ might reflect the quartz dilution effect (Cullers 1994; Figs 5, 6c). This phenomenon leads to the elimination of the REE-bearing minerals (in this case mainly phyllosilicates) from the sediment and, simultaneously, may cause preferential enrichment in heavy accessories, e.g., zircon (McLennan and Taylor 1991) as indicated by Fig. 8 b.

\section{Influence of minerals}

Positive correlations of $\Sigma$ REE with $\mathrm{Al}_{2} \mathrm{O}_{3}\left(0.85_{\text {[All] }}\right.$, $\left.0.57_{[\mathrm{GQ}]}, \quad 0.76_{[\mathrm{MF}]}, \quad 0.76_{[\mathrm{SF}]}\right), \quad \mathrm{K}_{2} \mathrm{O} \quad\left(0.63_{[\mathrm{Alll}]}, \quad 0.88_{[\mathrm{GQ}]}\right.$, $\left.0.55_{[\mathrm{MF}]}, \quad 0.14_{[\mathrm{SF}]}\right), \quad \mathrm{TiO}_{2} \quad\left(\begin{array}{llll}0.88_{[\mathrm{Alll}}, & 0.85_{[\mathrm{GQ}]}, & 0.69_{[\mathrm{MF}]},\end{array}\right.$ $\left.0.89_{[\mathrm{SF}]}\right), \mathrm{Nb}\left(0.89_{[\mathrm{Alll}]}, 0.88_{[\mathrm{GQ}]}, 0.52_{[\mathrm{MF}]}, 0.83_{[\mathrm{SF}]}\right)$ and $\mathrm{Th}$ $\left(0.90_{[\mathrm{Alll}}, 0.95_{[\mathrm{GQ}}, 0.80_{[\mathrm{MF}]}, 0.78_{[\mathrm{SF}]}\right)$ and negative correlation with $\mathrm{SiO}_{2}\left(-0.80_{[\mathrm{Alll}]},-0.85_{[\mathrm{GQ}]},-0.77_{[\mathrm{MF}]},-0.64_{[\mathrm{SF}}\right)$ all indicate that the REE content is mostly controlled by varying amounts of phyllosilicats together with rutile or ilmenite as a $\mathrm{Ti}$ and $\mathrm{Nb}$ carrier. Low correlations for $\mathrm{K}_{2} \mathrm{O}$ most probably reflect metamorphic remobilization. Weak positive correlations between $\Sigma \mathrm{REE}$ and $\mathrm{Zr}\left(0.48_{[\mathrm{All}]},-0.48_{[\mathrm{MF}]}\right.$, $\left.0.59_{[\mathrm{SF}]}\right)$ and $\mathrm{Hf}\left(0.54_{[\mathrm{All}]},-0.04_{[\mathrm{MF}]}, 0.58_{[\mathrm{SF}]}\right)$ suggest a minor influence by the mineral zircon on total REE contents in the MF and SF rocks. However, the GQ rocks are characterized by very high correlations between $\mathrm{Zr}$ and $\mathrm{Hf}$ (1.00), $\Sigma$ REE and $\mathrm{Zr}(0.91)$ or $\Sigma$ REE and Hf (0.93) documenting the strong influence of zircon on the chemical composition 


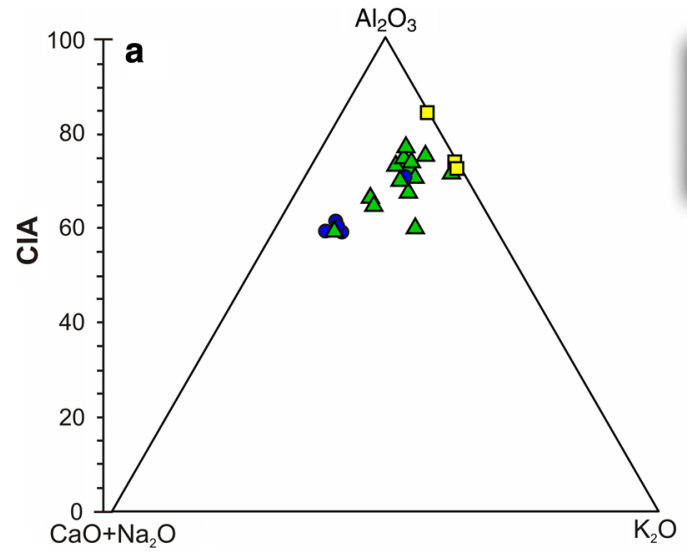

Fig. 7 a A-CN-K diagram and b A-CNK-FM diagram after Nesbitt and Young (1982) for OSD rocks analysed for this work. $\mathrm{A}=\mathrm{Al}_{2} \mathrm{O}_{3}$; $\mathrm{CN}=\mathrm{CaO}^{*}+\mathrm{Na}_{2} \mathrm{O} ; \mathrm{K}=\mathrm{K}_{2} \mathrm{O}$ (molecular proportion; $\mathrm{CaO} *=\mathrm{CaO}$

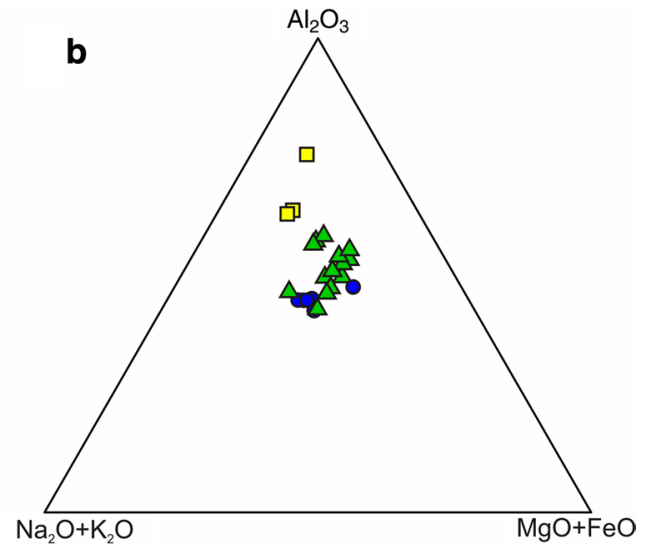

in silicate fraction only); $\mathrm{F}=\mathrm{FeO}, \mathrm{M}=\mathrm{MgO}$; CIA $=$ Chemical Index of Alteration of Nesbitt and Young (1982)
Fig. 8 Discrimination diagrams illustrating the influence of weathering and sediment recycling. a Th/U versus $\mathrm{Th} ; \mathbf{b} \mathrm{Th} /$ $\mathrm{Sc}$ versus $\mathrm{Zr} / \mathrm{Sc}$. Diagrams after McLennan et al. (1993). Grey fields as in Fig. 4
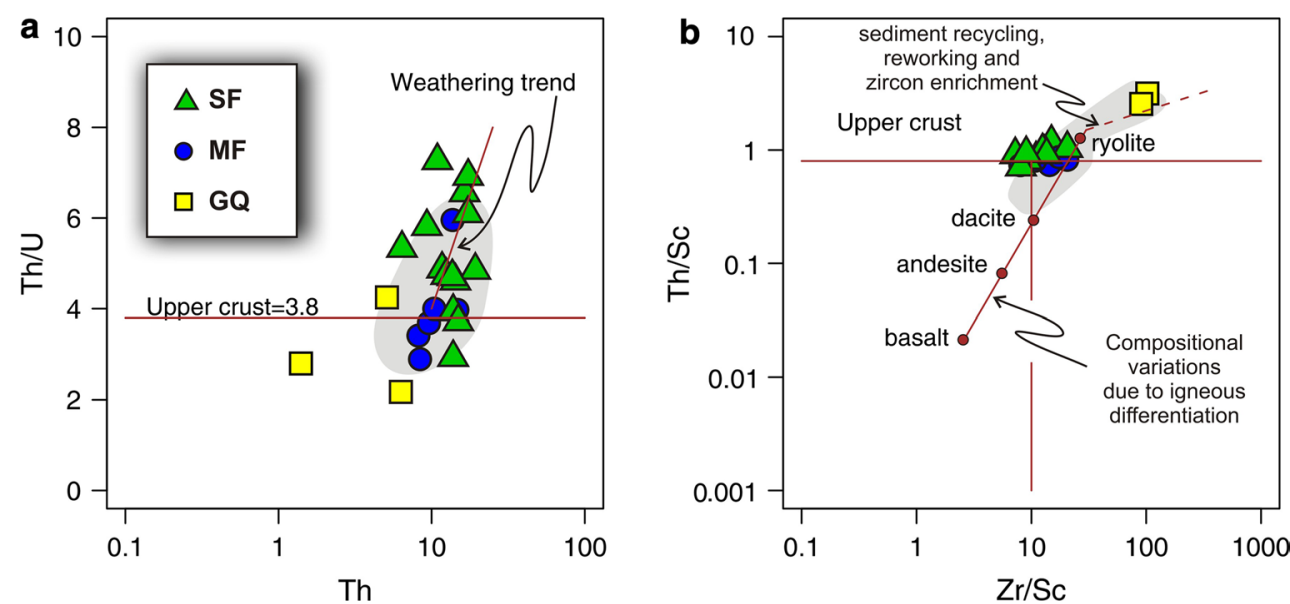

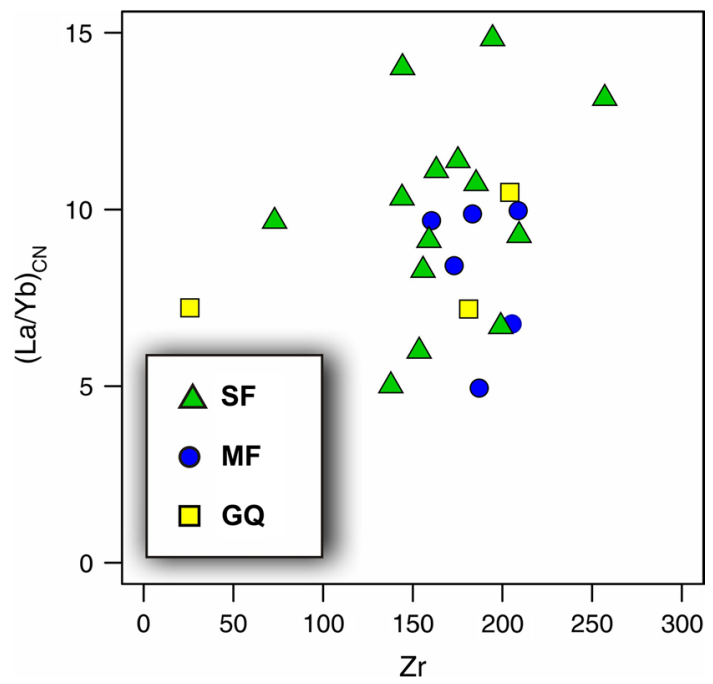

Fig. 9 Binary plot $(\mathrm{La} / \mathrm{Yb})_{\mathrm{CN}}$ versus $\mathrm{Zr}$ for metasediments of the OSD of the quartzites. This question will be further addressed in the following paragraph. The very weak correlation between $\Sigma R E E$ and $\mathrm{P}_{2} \mathrm{O}_{5}$ in the MF and SF rocks $\left(0.30_{\text {[All] }}\right.$, $\left.-0.38_{[\mathrm{MF}]},-0.12_{[\mathrm{SF}]}\right)$ indicates that apatite, xenotime or monazite did not control the REE distribution in these, contrasting with the important role of these minerals in the GQ as is indicated by a very good correlation of $\mathrm{P}_{2} \mathrm{O}_{5}$ with $\Sigma$ REE (0.95). A strong positive linear correlation between $\mathrm{Cr}$ and $\mathrm{Al}_{2} \mathrm{O}_{3}\left(0.59_{[\mathrm{Alll}}, 0.74_{[\mathrm{MF}]}, 0.82_{[\mathrm{SF}]}\right)$ suggests that in the MF and SF, the $\mathrm{Cr}$ content is controlled mainly by $\mathrm{Cr}-$ bearing aluminous phases such as micas. In contrast, $\mathrm{Cr}_{2} \mathrm{O}_{3}$ contents below the detection limit $\left(0.001 \% \mathrm{Cr}_{2} \mathrm{O}_{3}\right)$ in the GQ quartzites signals the absence of $\mathrm{Cr}$-bearing accessory oxides such as chromite in these rocks.

\section{Provenance}

As REE have short residence times in natural waters and are considered to transfer quantitatively from source region 
to sediment (Taylor and McLennan 1985; McLennan 1989; McLennan et al. 1993), they are good indicators of the bulk composition of sediment source rocks. The similar profiles of the chondrite-normalized REE patterns of the OSD rocks imply a common source for all (Fig. 5). Moreover, their REE patterns show enrichment of LREE relative to HREE (mean values $(\mathrm{La} / \mathrm{Yb})_{\mathrm{CN}}: 9.28_{[\mathrm{All}}, 8.29_{[\mathrm{GQ}}$, $\left.8.27_{[\mathrm{MF}]}, 9.93_{[\mathrm{SF}]}\right)$ and negative Eu-anomalies. Both features are characteristic of highly evolved magmatic rocks such as granitoids and felsic volcanics (Taylor and McLennan 1985; McLennan et al. 1993; Cullers 2000). Thus, the REE patterns identify the continental crust as the dominant sediment source.

The sediment provenance may be also assessed using $\mathrm{Th} / \mathrm{Sc}$ and $\mathrm{Zr} / \mathrm{Sc}$ values; both increase with magmatic evolution. Th, Sc and $\mathrm{Zr}$ also have short residence times in water and, as with the REE, are considered immobile during surface processes and, thus, are quantitatively transported from source region to deposition area. The MF and $\mathrm{SF}$ rocks are characterized by $\mathrm{Th} / \mathrm{Sc}$ values of $0.71-1.17$ (mean value $0.88 \pm 0.12$ ), and $\mathrm{Zr} / \mathrm{Sc}$ values of $7.25-20.59$ (mean value $12.97 \pm 4.32$ ). Thus, on the $\mathrm{Th} / \mathrm{Sc}$ vs. $\mathrm{Zr} / \mathrm{Sc}$ plot (Fig. 8b), the data cluster close to the felsic end member, confirming continental crust as the source area. In contrast, the GQ are characterized by considerably higher $\mathrm{Th} /$ Sc (2.55-3.15) and $\mathrm{Zr} / \mathrm{Sc}(90.55-102.05)$ values and the analyses locate along the line (Fig. 8b) indicative of sediment reworking and zircon enrichment.

Several other indicators also help in identifying the contribution from various types of source rocks to the sediment chemistry, e.g., the $\mathrm{TiO}_{2}$ and $\mathrm{Ni}$ relationship (Floyd et al. 1989), Cr-Th-La-Sc systematics (Taylor and McLennan 1985) and the La/Th vs. Hf/Yb diagram (Hladil et al. 2003). The OSD rocks are characterized by low $\mathrm{TiO}_{2}$ and Ni values (Fig. 10a), typical for a felsic source essentially lacking mafic rocks. The position of the OSD rocks on the $\mathrm{La} / \mathrm{Th}$ vs. Hf/Yb plot (Fig. 10b) also indicates a source area dominated by felsic magmatic rocks. Moreover, the values of $\mathrm{La} / \mathrm{Sc}, \mathrm{Sc} / \mathrm{Th}$ and $\mathrm{Cr} / \mathrm{Th}$ suggest that the metasediment protoliths were chemically similar to granites (Condie 1993) and sands derived from acidic magmatic rocks (Taylor and McLennan 1985; Table 4).

\section{Tectonic setting of deposition}

The sediment chemistry may also help to identify the tectonic setting of their deposition (e.g., Bhatia 1985; Bhatia and Crook 1986; McLennan et al. 1990). Indeed, they may hold the only evidence pointing to their palaeotectonic environment of deposition (Bhatia and Crook 1986). Thus, attempts were made to correlate the chemistry of metasediments with potential tectonic depositional settings using discrimination criteria based on both major- and trace elements capable of fingerprinting the tectonic setting of ancient sedimentary basins (e.g., Bhatia 1983; Bhatia and Crook 1986). Although the criteria used below were originally developed for sandstones, they have been successfully applied to finer-grained sediments such as mudstones and even suites of metasediments of unknown protholith (e.g., Girty et al. 1993; Lopez de Luchi et al. 2003; Patočka and Storch 2004; Xu Deru et al. 2007). Diagrams based on immobile trace elements developed by Bhatia and Crook (1986) allow discrimination between four tectonic settings deemed the most common for sandstone deposition, i.e., oceanic island arc (OIA), CIA, active continental margin (ACM) and PM. Inspection of their Sc-Th-Zr, Th-La-Sc ternary diagrams and the $\mathrm{Ti} / \mathrm{Zr}$ versus $\mathrm{La} / \mathrm{Sc}$ diagrams show that all the analyses representing the MF and SF rocks fall within the CIA or ACM fields (Fig. 11a-d). The GQ rocks clearly depart from this pattern; analyses plot in the PM field in all diagrams (Fig. 11a-d). However, on the $\mathrm{TiO}_{2}$ vs. $\mathrm{Fe}_{2} \mathrm{O}_{3}+\mathrm{MgO}$ diagram, data for the MF and SF scatter between the ACM, CIA and OIA fields (Fig. 11c); the cause is variable $\mathrm{TiO}_{2}$. However, these rocks are characterized by similar values of Ti/Zr and define a rather coherent
Fig. 10 a Binary plot $\mathrm{TiO}_{2}$ versus $\mathrm{Ni}$; $\mathbf{b}$ binary plot of $\mathrm{La} / \mathrm{Th}$ versus $(\mathrm{Hf} / \mathrm{Yb}) * 10$
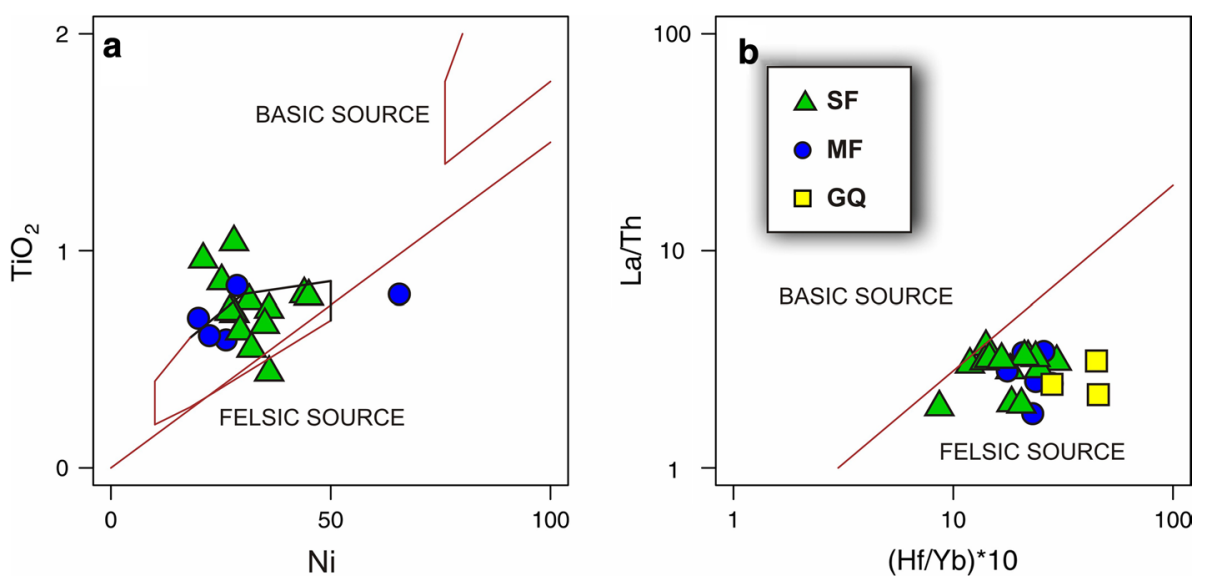
Table 4 Elemental ratios typical of granites, andesites, ophiolites and sands from basic and silicic rocks

\begin{tabular}{lllllccc}
\hline Ratio & Granites $^{\mathrm{a}}$ & Andesites $^{\mathrm{a}}$ & Ophiolites $^{\mathrm{b}}$ & Sands from basic rocks $^{\mathrm{c}}$ & Sands from acid rocks $^{\mathrm{c}}$ & This study MF and SF $^{\text {This study GQ }}$ \\
\hline $\mathrm{La} / \mathrm{Sc}$ & 8.00 & 0.90 & 0.25 & $0.4-1.1$ & $2.5-16$ & $1.3-3.3$ & $5.6-9.8$ \\
$\mathrm{Sc} / \mathrm{Th}$ & 0.28 & 4.65 & 56.0 & $20-25$ & $0.05-1.2$ & $0.8-1.4$ & $0.3-0.4$ \\
$\mathrm{Cr} / \mathrm{Th}$ & 0.44 & 9.77 & 410 & $22-100$ & $0.5-7.7$ & $4.3-8.0$ & n.a. \\
\hline
\end{tabular}

The upper continental crust (UCC), lower continental crust (LCC) and oceanic crust (OC), and from examined rocks reported in this study

a Condie (1993)

b Spadea et al. (1980)

c Taylor and McLennan (1985)

Fig. 11 Discrimination diagrams showing tectonic setting of deposition of the protoliths to the OSD metasediments. (diagrams after Bhatia and Crook 1986). Abbreviations as in Fig. 4
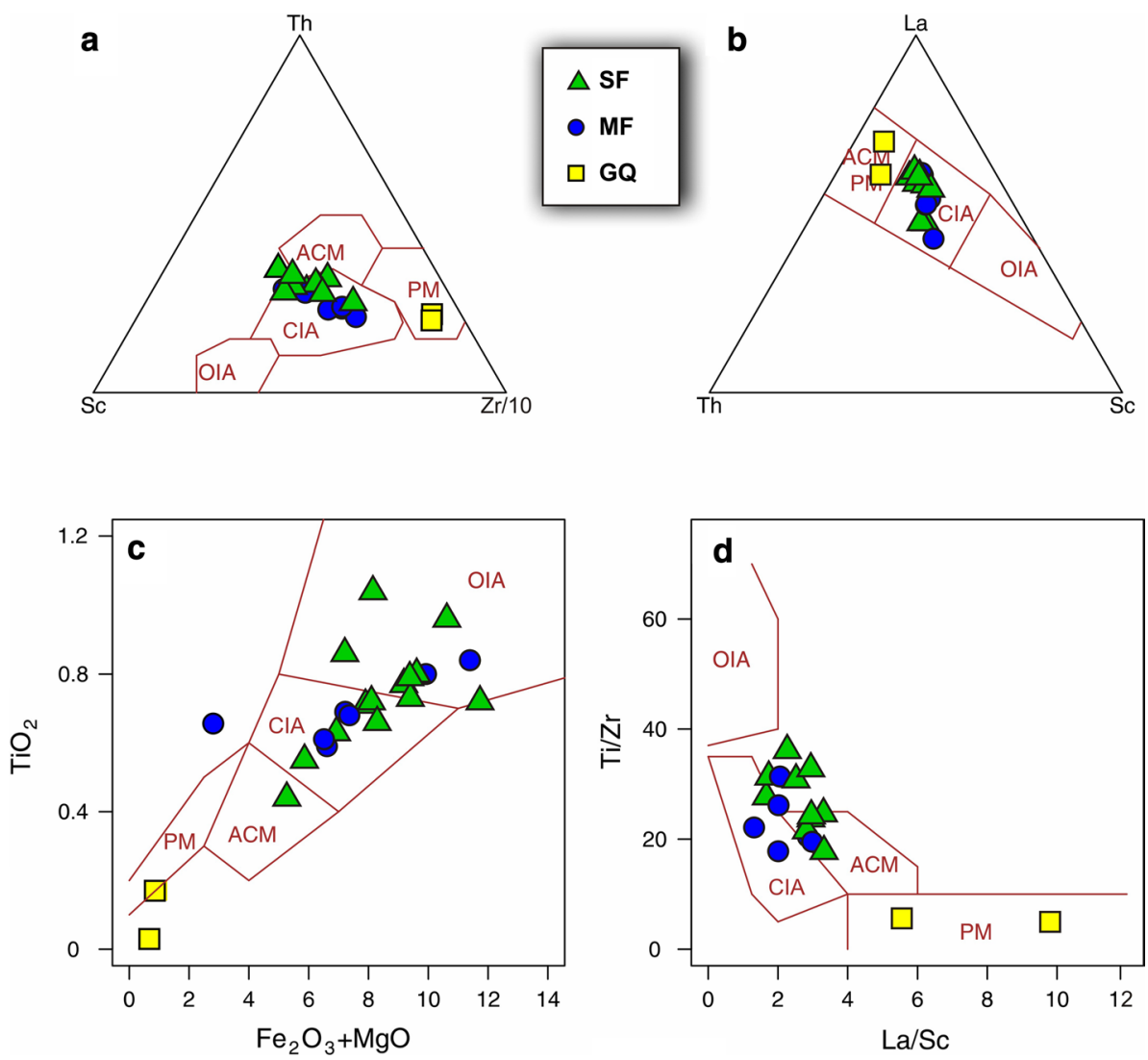

group within or close to the CIA and ACM fields on the Ti/Zr vs. La/Sc diagram (Fig. 11d).

According to Bhatia and Crook (1986), discrimination between supra-subduction depositional settings and PM environments is possible using ratios of several trace elements, e.g., Th/U, Zr/Hf, Zr/Th, Zr/Nb, Zr/Y, Nb/Y, La/Y, $\mathrm{La} / \mathrm{Th}, \mathrm{La} / \mathrm{Sc}, \mathrm{Th} / \mathrm{Sc}$ and $\mathrm{Ti} / \mathrm{Zr}$. A selection of these ratios for the OSD rocks normalized to the composition of PM sediments is shown on Fig. 12. The GQ rocks do not reveal any important anomalies in these ratios but are very similar to typical PM sediments (Fig. 12a). The only exception is $\mathrm{Th} / \mathrm{U}$ which is lower than that for siliciclastics deposited on a PM. On the other hand, several pronounced anomalies characterize the rocks of both the MF and the SF, e.g.,
$\mathrm{Zr} / \mathrm{Nb}$ and $\mathrm{Ti} / \mathrm{Zr}$ values differ substantially from those of PM sediments (Fig. 12b, c). These chemical characteristics may suggest deposition of the original sediments in a subduction tectonic setting, presumably related to an ACM or CIA.

Regional implications and correlations

Data presented here document strong similarities between Neoproterozoic and Early Palaeozoic rock Units in the OSD and Saxo-Thuringian Zone and consequently also other rock successions of similar age cropping out in the western part of the Variscan Belt of Europe (e.g., OssaMorena Zone, Pereira et al. 2006). This implies that these 

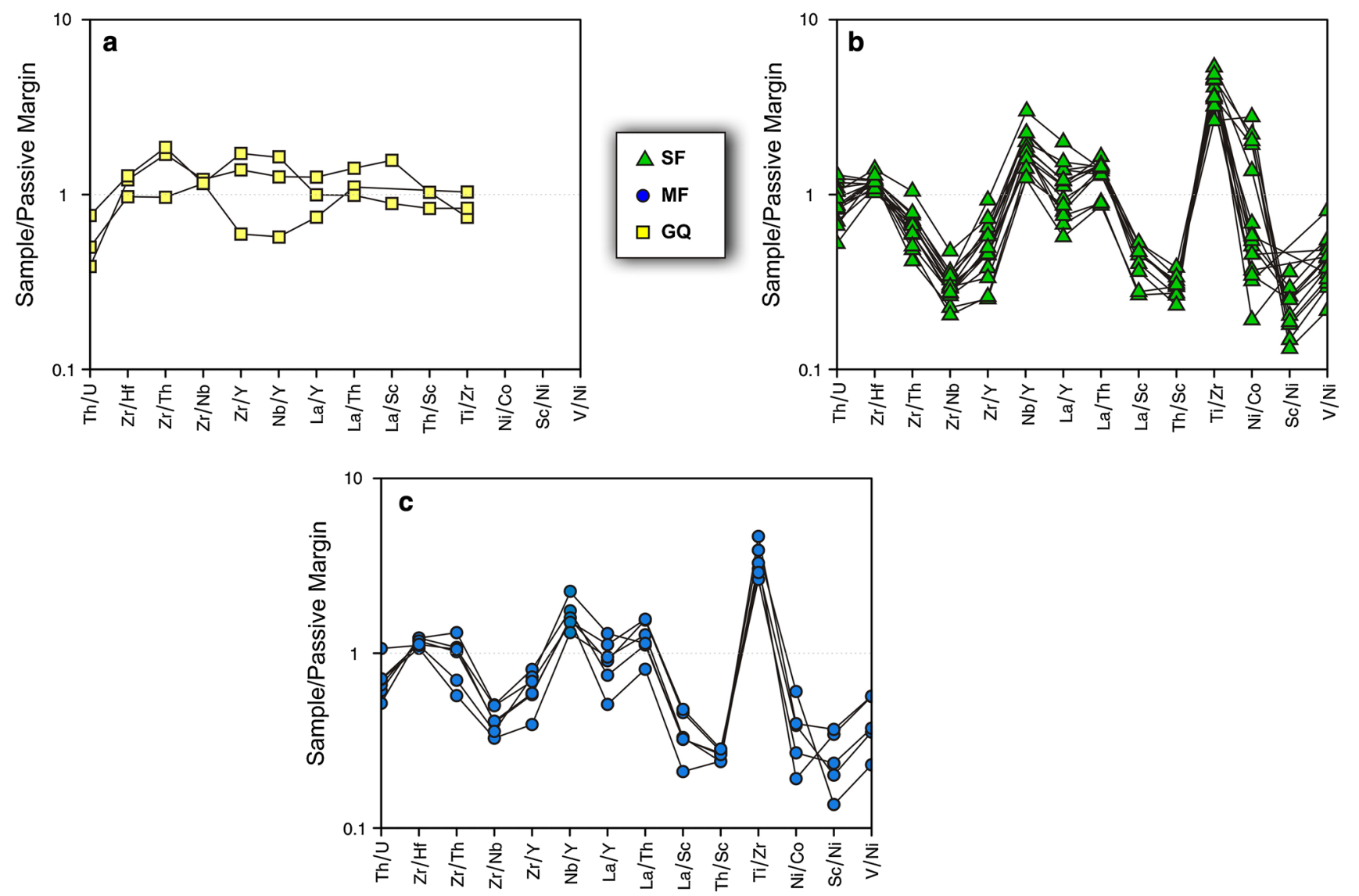

Fig. 12 Passive margin-normalized trace-element ratio patterns (diagrams after Bhatia and Crook 1986) for the OSD metasediments

crustal fragments were collectively part of the northern Gondwana margin and consequently bear a record of similar geodynamic scenario for Neoproterozoic and Early Palaeozoic times. However, more complex lithology is observed in both the Saxo-Thuringian and Ossa-Morena Zones in comparison with the OSD, as the latter represents rather small crustal fragment. Nevertheless, similarities comprise both lithological, age and geochemical features of metasediments.

Detrital zircon ages for volcano-sedimentary successions in the OSD indicate that these are coeval with deformed and metamorphosed complexes exposed in the Saxo-Thuringian Zone. Maximum deposition ages of $563 \pm 6$ Ma for the MF and $532 \pm 6$ Ma for the SF (Mazur et al. 2012) are similar to those of volcano-sedimentary successions from the external domain of the Saxo-Thuringian Zone, which has maximum depositional ages of 566-563 Ma for an older succession, e.g., the Rothstein Formation, and of ca $540 \mathrm{Ma}$ for younger sediments, e.g., the Zwethau Formation (Linnemann et al. 2008). Also, the 30 Ma time interval between the deposition of the MF and that of the SF is comparable with the interval seen in the Saxo-Thuringian Zone (Linnemann et al. 2008). Moreover, zircon age spectra reported for the MF, SF and GQ rocks are similar to those that have been documented from the Saxo-Thuringian Zone (e.g., Linnemann et al. 2008). This demonstrates that metasediments discussed here are products of erosion of continental crust most probably represented by the West African margin of Gondwana as proposed by Nance et al. (2008).

Volcano-sedimentary sequences of the SF and the GQ were deposited on Cadomian basement. In the SaxoThuringian Zone, a well-exposed Cadomian basement is represented by, e.g., the ca 570-540 Ma Western Lausitz Granitoids (Korytowski et al. 1993; Linnemann et al. 2000; Żelaźniewicz et al. 2004). Further to the east, Cadomian basement only locally emerges from below younger sequences and is exposed in the Fore-Sudetic Block in the vicinity of Wądroże Wielkie as $548 \mathrm{Ma}$ granodiorites (Fig. 1; Żelaźniewicz et al. 2004). In age terms, these granitoid rocks are coeaval with Cadomian orthogneisses exposed elsewhere in the Saxo-Thuringian Zone. Thus, it seems probable that in the OSD, Cadomian basement is buried below the volcano-sedimentary sequences there, and likely copiously intruded by 500 Ma granites later transformed into the Śnieżnik orthogneiss. 


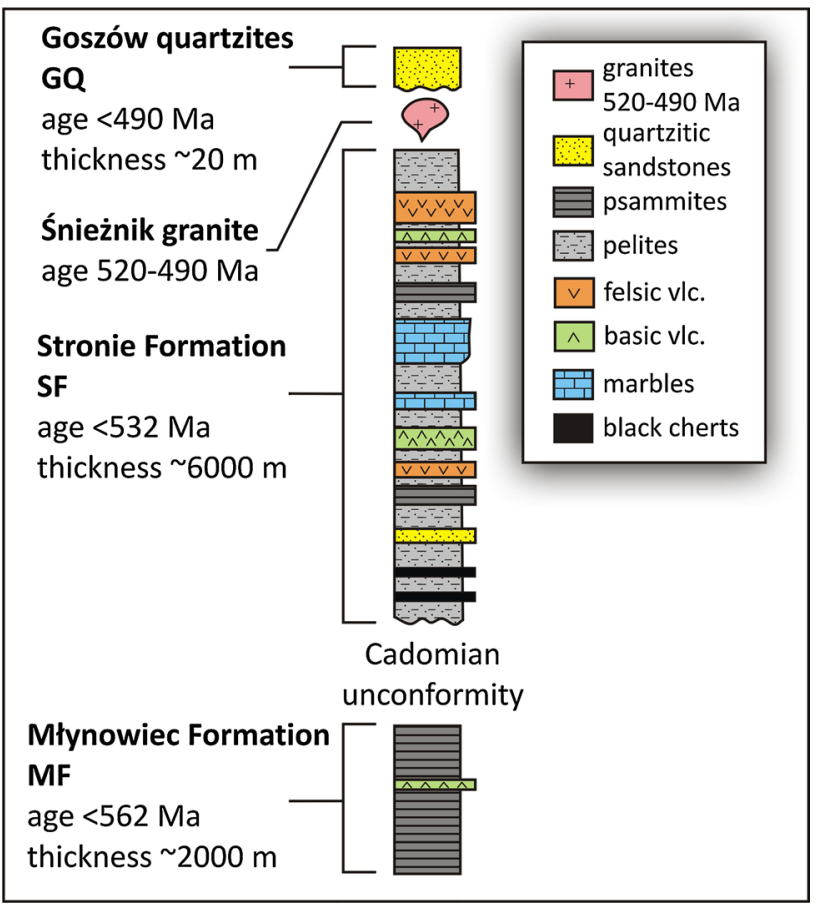

Fig. 13 Lithostratigraphy of the Młynowiec-Stronie Group based on mapping (Don et al. 2003) and U-Pb SHRIMP zircon data (Mazur et al. (2012)

In geochemical composition, the rocks of the MF and SF show several features typical of sediments deposited in supra-subduction sedimentary basins. Detritus filling these basins must have been supplied by erosion of evolved felsic igneous rocks bearing an arc signature. Moreover, the identical chemical characteristics of the MF and SF rocks despite their different depositional ages suggest that there was, over time, no important change in sediment source or in detritus type filling those basins. This same situation has already been recognized both for the Neoproterozoic and the Early Cambrian metasediments of the Saxo-Thuringian (Linnemann and Romer 2002) and the Ossa-Morena Zones (Pereira et al. 2006). Moreover, the geochemical similarity of the rocks of the MF and the SF to sediments from the Saxo-Thuringian Zone (Linnemann and Romer 2002) suggests that a common tectonic setting may be key to explaining the origin of the Neoproterozoic to Cambrian volcanosedimentary successions in the OSD and other fragments of the Cadomian orogen preserved in the European Variscan Belt. Following the model of Linnemann et al. (2007), it may be hypothesized that deposition of the older monotonous MF preceded events related to the Cadomian orogeny and occurred in a back-arc setting during the time span preceding $540 \mathrm{Ma}$. Thus, the chemical affinity of the deformed and metamorphosed volcano-sedimentary successions of the OSD, as reported here, with the Neoproterozoic to Early Palaeozoic volcano-sedimentary successions widespread in the Saxo-Thuringian Zone (Linnemann and Romer 2002) corroborate the isotopic data and the interpretations that the OSD represents an exhumed fragment of the Saxo-Thuringian Zone (Chopin et al. 2012; Mazur et al. 2012).

Deposition of the protolith of the younger variegated SF could have been related to erosion of the newly formed Cadomian orogen, resulting in geochemical characteristics similar to those of the MF. However, felsic and basic volcanics and tuffites interfingered with the SF metasediments show several chemical features typical of volcanites generated in a supra-subduction setting related to a back-arc environment. Basic metavolcanic rocks predominantly of MORB-type with supra-subduction zone affinities and rare alkaline OIB-like metabasalts have previously been interpreted as recording the evolution from a back-arc setting to a rifting environment (Floyd et al. 1996; Ilnicki et al. 2013). In addition, acid metavolcanics interfingering the SF show continental crust affinities and also some features indicative of magmatism in a supra-subduction environment have been interpreted as due to back-arc spreading (Murtezi 2006). The protolith age of at least some of the felsic volcanics is $500 \mathrm{Ma}$ (Murtezi and Fanning 2005).

Considering the chemistry of the metasediments and the interfingered metavolcanic rocks of the SF, it is possible that their origin involved back-arc spreading driven by slab retreat and the final opening of the Rheic Ocean as proposed by, e.g., Murphy et al. (2009) and Martinez et al. (2009). In this context, the chemical composition of the SF rocks could reflect not only the erosion of the freshly exhumed Cadomian orogen, as suggested for the Early Cambrian volcano-sedimentary succession of the SaxoThuringian Zone by, e.g., Linnemann et al. (2004), Linnemann et al. (2008) and Mazur et al. (2012) but also the tectonic setting of its sedimentary basin.

The GQ show features typical of sediments deposited on a passive continental margin which, together with their relatively young maximum deposition age (ca $490 \pm 9 \mathrm{Ma}$; Mazur et al. 2012), allows correlation with Lower Ordovician quartz-rich sandstones well-known from central and western parts of the European Variscan Belt (e.g., Linnemann and Romer 2002). Thus, these quartzites might be equivalents of the Armorican Quartzite Formation in Portugal and Spain related to the opening of the Rheic Ocean (Linnemann et al. 2008; Sánchez-García et al. 2008).

Towards an evolutionary model for the position of volcano-sedimentary successions within the OSD

Currently available data for the OSD indicate that the widely accepted lithostratigrahic scheme of the Stronie and MFs and of the GQ (Fischer 1936; Don and Dowidar 1988; Don et al. 1990) needs substantial revision. Recently, 


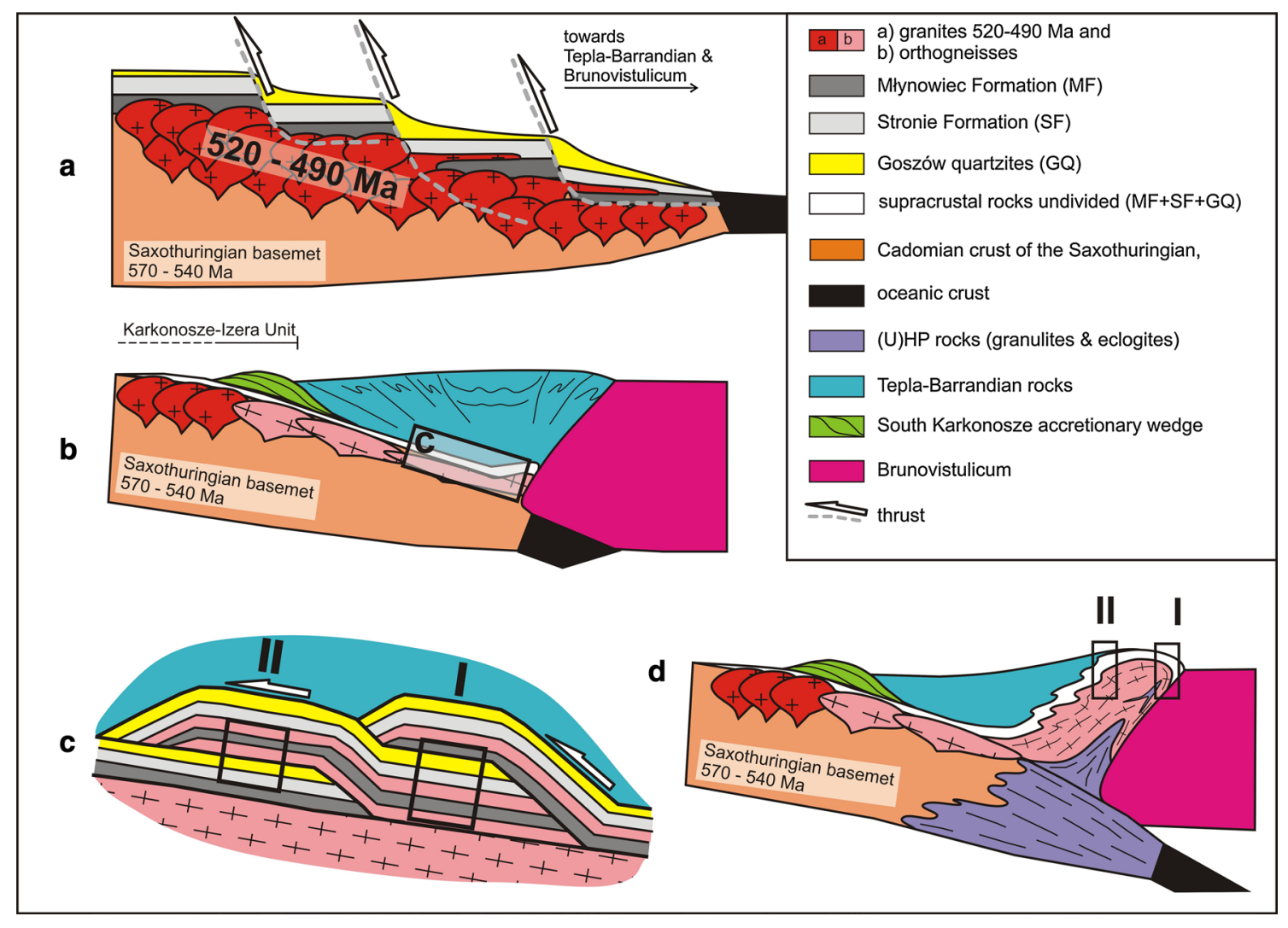

Fig. 14 Idealized model based on Chopin et al. (2012) showing tectonic evolution of the OSD and tectonic position of volcano-sedimentary successions: a PM of Saxo-Thuringia. b Underthrusting of SaxoThuringia PM under Teplá-Barrandian and development of crystalline nappes. c Increasing strain-induced development of series of thrust slices within the sequence comprising basement gneisses and metasedimentary cover. d Formation of the dome

which may be explained by thrusting. Based on differences in metamorphic record, three tectonic units within the volcano-sedimentary succession in the Bystrzyckie Mts have been interpreted as fragments of three distinct nappes that were later jointly refolded (Szczepański 2010a). Although the model of Chopin et al. (2012) for the tectonics and structural evolution of the OSD apparently precludes or at least does not require large-scale nappes in this part of the Sudetes the explanation of the inferred lithotectonic scheme for the metasedimentary rocks in the OSD presented above may allow a nappe-tectonic element to be merged with the model of Chopin et al. (2012). According to that model, the Saxo-Thuringian PM started to subduct under the Brunia continent at ca 370-360 Ma. At that time the crystalline Saxo-Thuringian basement was covered by volcanosedimentary succession of Neoproterozoic to Ordovician age comprising, in part the future OSD, the Młynowiec and SFs, and the GQ. The entire succession was intruded by the ca $500 \mathrm{Ma}$ granitic precursor of the orthogneiss which, in places, may have penetrated the unconformity between the MF and SF (Fig. 14a). Increasing strain during continuing subduction could conceivably have led to Młynowiec and SFs which are both older, a juxtaposition 


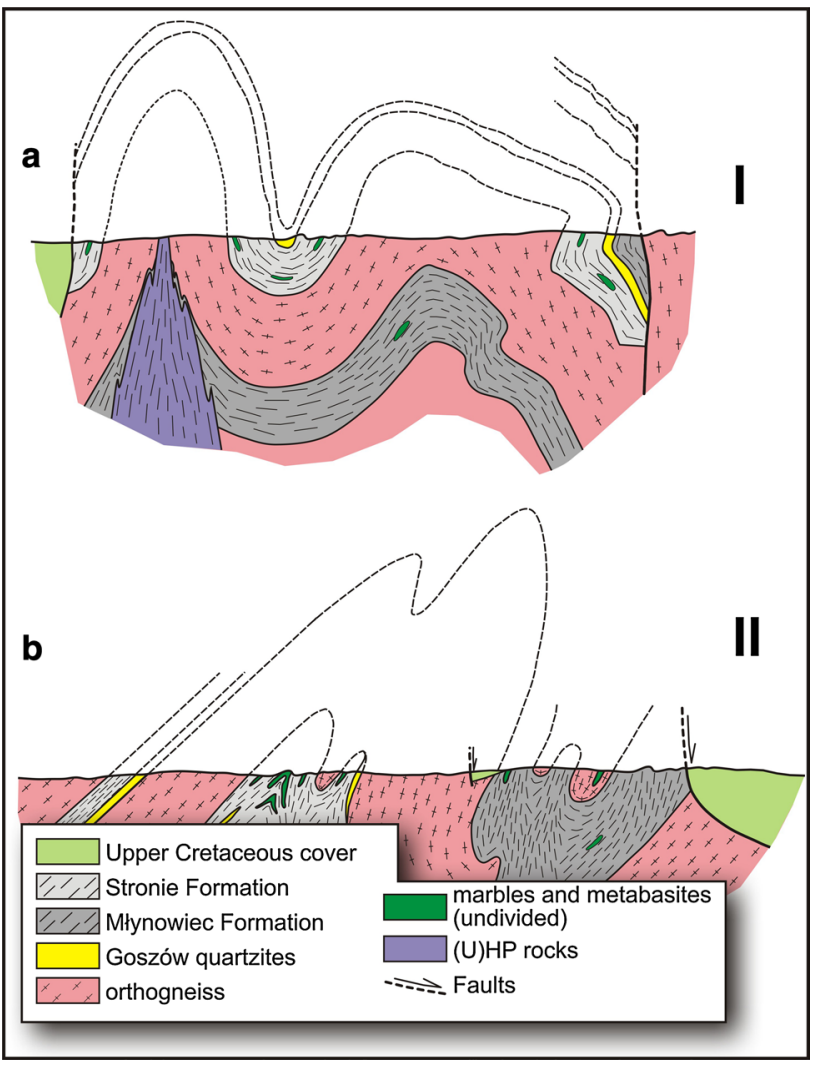

Fig. 15 a Schematic cross section showing possible tectonic position of metasedimentary succession in the Śnieznik Massif. b Schematic cross section based on Szczepański (2010a) showing tectonic position of metasedimentary rocks in the Bystrzyckie Mts

development of series of thrust slices within the sequence comprising both basement gneisses and metasedimentary cover (Fig. 14b, c). Simultaneously, accretionary wedge was developed, which according to Chopin et al. (2012) is represented by the South Karkonosze Unit located in the easternmost part of the Karkonosze-Izera Massif. Thrusting resulted in imbrication of the whole sequence. Thus, the oldest MF was thrust on top of the youngest, the GQ, and even on the top of orthogneiss bodies (Fig. 14c). Consequently, in places, the youngest GQ were tectonically inserted between the SF and the MF (Fig. 14c-I) whereas, elsewhere, both the SF together with the GQ were separated from the MF by orthogneiss bodies (Fig. 14c-II). Horizontal compression driven by continuing underthrusting of the whole sequence led to the development of the asymmetrical antiformal structure and exhumation of the whole complex as proposed by Chopin et al. (2012) and presented on Fig. 14d. Coeval HT metamorphism triggered partial migmatization leading to the development of the Gierałtów orthogneisses.

The Młynowiec area is located on the steep eastern limb of the OSD (SM; Fig. 14d-I) where the lithotectonic sequence of the volcano-sedimentary succession starts with the MF, is followed by the GQ and topped with the SF (Fig. 15a). This interpretation implies a major thrust between the GQ and the structurally higher SF (Fig. 14c-I). However, the western part of the OSD, located on the normal limb of the dome (Fig. 14d-II), comprises alternating orthogneiss bodies with the rocks of the MF in the Młoty Unit and of the SF in the Poręba and Niemojów Units (Fig. 15b). This may reflect large-scale folding, in agreement with the structural data and models of Szczepański (2010a) and Chopin et al. (2012). If this is so, tectonic units located more to the east should record higher pressures than those more to the west. This is indeed the case. Paragneisses (sample s25 of Szczepański 2010a) from the Młoty unit records a maximum pressure of $10.2 \mathrm{kbar}$, whereas mica schists of the Poręba Unit (sample s134 of Szczepański 2010a) records maximum pressures $<7.9 \mathrm{kbar}$ at the same $\mathrm{D}_{2}$ deformation episode. This is consistent with easterly units in the Bystrzyckie Mts (Młoty Unit) having experienced a greater degree of underthrusting and exhumation than did those further to the west (Poręba Unit). This eastward trend of pressure increase is, to some extent, also documented by phyllite D29 (4.3 Kbar) collected from the Nové Město Unit and mica schists from more to the east represented by samples D7 and D13 (6.9-9.6 kbar) from the Orlica Mts (Mazur et al. 2005). Furthermore, very high pressures of up to 18 kbars (Štípská et al. 2004) and possibly >25 kbar (Bakun-Czubarow 1992; Kryza et al. 1996; Bröcker and Klemd 1996) have been recorded in the eastern part of the OSD where eclogites and granulites are found.

The P-T data available for rocks from the western flank of the OSD enhance credibility to the model proposed here. In this part of the dome (Bystrzyckie Mts.) three tectonic units (Fig. 2, inset) with strikingly different PT history were documented (Szczepański, 2010a, b). This allows to interpret them in terms of tectonically juxtaposed fragments of nappes. Interestingly, even in the eastern flank of the OSD, the documented PT history of rock complexes located in different parts of the dome is varied (Chopin et al. 2012) providing further support to the nappe hypothesis. Unfortunately, so far no traces of ductile shear zones which could mark base of nappes have been documented. It is conceivable that at least in part, the shear zones related to thrusting might have been obscured or even destroyed by later HT metamorphism and migmatization of the orthogneisses and emergence of Gierałtów-type migmatitic orthogneiss.

According to the model presented here for the western part of the OSD (Bystrzyckie Mts), the major thrust zones should be located at the bottom of the orthogneiss bodies. This is not in accord with the original proposition of Szczepański (2010a), but a lack of reliable data on the metamorphic evolution of the orthogneiss bodies and poor exposure considerably hampers meaningful correlation and precludes unequivocal inferences. 
Modification of the model of Chopin et al. (2012) by application of the nappe tectonics explains the paradox that despite geochemical and lithological similarities between the volcano-sedimentary successions in the OSD and other fragments of the Cadomian basement incorporated in the Variscan Belt of Europe (e.g., Saxo-Thuringian Zone or Ossa-Morena Zone), there are important differences in documented tectonostratigraphy of the Neoproterozoic-Early Palaeozoic rock successions in these terrains. It also allows us to advocate hypothesis that the OSD corresponds to a recycled Saxo-Thuringian crust subducted and later exhumed from beneath the TB terrane in front of a rigid massif represented by Brunia (Chopin et al. 2012; Mazur et al. 2012).

\section{Conclusions}

New geochemical data underpin the following conclusions about the provenance, depositional setting and lithostratigraphy of volcano-sedimentary successions in the OSD.

1. Neoproterozoic (Cadomian) to Cambro-Ordovician clastic sediments cropping out in the OSD were deposited at the peri-Gondwanan margin and derived from erosion of felsic volcanic rocks. The chemical signature of the sediments is thought to be related to the sediment source. The analysed metasediments are characterized by LREE enrichment, negative Eu-anomalies and relatively flat HREE patterns. In contrast, the GQ stand out as characterized by considerably lower traceelement abundances, including REE.

2. Trace-element data clearly suggest that the metasediments were derived from felsic rather than from mafic and/or ultramafic source rocks.

3. The protoliths of the metasedimentary successions of both the MF and SF were deposited in a back-arc basins. Importantly, the MF was deposited before the Cadomian orogenesis, after which the SF was deposited during incipient opening of the Rheic Ocean in response to slab retreat.

4. The GQ show chemical features typical of sediments deposited on a PM.

5. The new tectonic scenario explaining the lithostratigraphy and lithotectonics of the volcano-sedimentary succession in the OSD proposed here builds on the tectonic model of Chopin et al. (2012).

6. We advocate the hyphothesis that the three metasedimentary successions of the OSD, deposited in different tectonic environments, represent the easternmost extension of the Saxo-Thuringian Zone. Therefore, the studied metasedimentary successions provide an important insight into Cadomian and post-Cadomian development of the Bohemian massif.
Acknowledgments The authors thank Christian Dullo for editorial handling of the paper. The authors are indebted to Ulf Linnemann, John Winchester and Padraigh Kennan for their helpful comments on the earlier versions of the manuscript, and corrections of the English of the text. Grants from the University of Wrocław (1017/S/ING) and from the Faculty of Geology, University of Warsaw (BW 1726/15 and BSt 1241/4), are gratefully acknowledged.

Open Access This article is distributed under the terms of the Creative Commons Attribution License which permits any use, distribution, and reproduction in any medium, provided the original author(s) and the source are credited.

\section{References}

Arenas R, Martínez Catalán JR, Sánchez Martínez S, FernándezSuárez J, Andonaegui P, Pearce JA, Corfu F (2007) The Vila de Cruces Ophiolite: a remnant of the early Rheic Ocean in the variscan suture of Galicia (Northwest Iberian Massif). J Geol 115:129-148

Armstrong-Altrin JS, Verma SP (2005) Critical evaluation of six tectonic setting discrimination diagrams using geochemical data of Neogene sediments from known tectonic settings. Sediment Geol 177:115-129

Bakun-Czubarow N (1992) Quartz pseudomorphs after coesite and quartz exsolutions in eclogitic omphacites of the Złote Mountains in the Sudetes (SW Poland). Arch Miner 48:3-25

Bau M (1991) Rare-earth element mobility during hydrothermal and metamorphic fluid-rock interaction and the significance of the oxidation state of europium. Chem Geol 93:219-230

Bhatia MR (1983) Plate tectonics and geochemical composition of sandstones. J Geol 91:611-627

Bhatia MR (1985) Rare earth element geochemistry of Australian Paleozoic graywackes and mudrocks; provenance and tectonic control. Sediment Geol 45:97-113

Bhatia MR, Crook KAW (1986) Trace element characteristics of graywackes and tectonic setting discrimination of sedimentary basins. Contrib Miner Petrol 92:181-193

Bhatia MR, Taylor SR (1981) Trace-element geochemistry and sedimentary provinces; a study from the Tasman Geosyncline, Australia. Chem Geol 33:115-125

Bierlein FP (1995) Rare-earth element geochemistry of clastic and chemical metasedimentary rocks associated with hydrothermal sulphide mineralisation in the Olary Block, South Australia. Chem Geol 122:77-98

Bröcker M, Klemd R (1996) Ultrahigh-pressure metamorphism in the Śnieżnik Mountains (Sudetes, Poland): P-T constraints and geological implications. J Geol 104:417-433

Chopin F, Schulmann K, Skrzypek E, Lehmann J, Dujardin JR, Martelat JE, Lexa O, Corsini M, Edel JB, Štípská P, Pitra P (2012) Crustal influx, indentation, ductile thinning and gravity redistribution in a continental wedge building a Moldanubian mantled gneiss dome with underthrust Saxothuringian material (European Variscan belt). Tectonics 31

Condie KC (1993) Chemical composition and evolution of the upper continental crust; contrasting results from surface samples and shales. Chem Geol 104:1-37

Cullers RL (1994) The controls on the major and trace element variation of shales, siltstones, and sandstones of PennsylvanianPermian age from uplifted continental blocks in Colorado to platform sediment in Kansas, USA. Geochim Cosmochim Acta 58:4955-4972

Cullers RL (2000) The geochemistry of shales, siltstones and sandstones of Pennsylvanian-Permian age, Colorado, USA: 
implications for provenance and metamorphic studies. Lithos 51:181-203

Dickinson WR, Valloni R (1980) Plate settings and provenance of sands in modern ocean basins. Geology 8:82-86

Don J, Dowidar H (1988) Goszów quartzites and the problem of the Młynowiec Series (Śnieżnik Metamorphic Massif, Sudetes). Bull Polish Acad Sci Earth Sci 36:239-252

Don J, Dumicz M, Wojciechowska I, Żelaźniewicz A (1990) Lithology and tectonics of the Orlica-Śnieżnik Dome, Sudetes; recent state of knowledge. N Jb Geol Palaeont Abh 179:159-188

Don J, Skácel J, Gotowała R (2003) The boundary zone of the East and West Sudetes on the 1:50 000 scale geological map of the Velké Vrbno, Staré Město and Śnieżnik Metamorphic Units. Geol Sudet 35:25-59

Dumicz M (1964) Budowa geologiczna krystaliniku Gór Bystrzyckich. Geol Sudet 1:169-208

Fajst M (1976) Nová diskordance v prekambriu českého masivu. Časopis Mineral Geol 21:257-275

Fernandez-Suarez J, Garcia FD, Jeffries TE, Arenas R, Abati J (2003) Constraints on the provenance of the uppermost allochthonous terrane of the NW Iberian Massif: inferences from detrital zircon $\mathrm{U}-\mathrm{Pb}$ ages. Terra Nova 15:138-144

Fischer G (1936) Der Bau des Glatzer Schneegebirges. Jb Preuss Geol Landesanst 56:712-732

Floyd PA, Winchester JA, Park RG (1989) Geochemistry and tectonic setting of Lewisian clastic metasediments of the early Proterozoic Loch Maree Group of Gairloch, NW Scotland. Precambrian Res 45:203-214

Floyd PA, Winchester JA, Ciesielczuk J, Lewandowska A, Szczepański J, Turniak K (1996) Geochemistry of early Palaeozoic amphibolites from the Orlica-Snieżnik dome, Bohemian massif: petrogenesis and palaeotectonic aspects. Int J Earth Sci 85(2):225-238

Girty GH, Hanson AD, Yoshinobu AS, Knaack C, Johnson D (1993) Provenance of Paleozoic mudstones in a contact metamorphic aureole determined by rare earth element, Th, and Sc analyses, Sierra Nevada, California. Geology 21:363-366

Girty GH, Hanson AD, Johnson C, Knaack D (1994) Provenance determined by REE, Th, and Sc analyses of metasedimentary rocks, Boyden Cave roof pendant, central Sierra Nevada, California. J Sediment Res 64:68-73

Gunia T (1974) Mikroflora prekambryjskich wapieni okolicy Dusznik Zdroju (Sudety Środkowe). Ann Soc Geol Pol 44:65-92

Gunia T (1989) Acritarcha i mikroproblematyki z wapieni krystalicznych okolicy Romanowa Górnego (Sudety SrodkoweKrowiarki). Geol Sudet 24:101-135

Gunia T, Wierzchołowski B (1979) Mikroproblematyki z paragnejsów Gór Bystrzyckich (Sudety). Geol Sudet 14:7-25

Herron MM (1988) Geochemical classification of terrigenous sands and shales from core or log data. J Sediment Res 58:820-829

Hladil J, Patočka F, Kachlik V, Melichar R, Hubacik M (2003) Metamorphosed carbonates of Krkonose Mountains and Paleozoic evolution of Sudetic terranes (NE Bohemia, Czech Republic). Geol Carpath 54:281-297

Holland HD (1978) The chemistry of the atmosphere and oceans. Wiley, New York

Ilnicki S, Szczepański J, Pin C (2013) From back-arc to rifted margin: geochemical and $\mathrm{Nd}$ isotopic records in Neoproterozoic?Cambrian metabasites of the Bystrzyckie and Orlickie Mountains (Sudetes, SW Poland). Gondwana Res 23:1104-1121

Janoušek V, Farrow CM, Erban V (2006) Interpretation of whole-rock geochemical data in igneous geochemistry; introducing geochemical data toolkit (GCDkit). J Petrol 47:1255-1259

Jastrzębski M (2009) A Variscan continental collision of the West Sudetes and the Brunovistulian terrane: a contribution from structural and metamorphic record of the Stronie Formation, the Orlica-Śnieżnik Dome, SW Poland. Int J Earth Sci 37:1-26
Jastrzębski M, Żelaźniewicz A, Nowak I, Murtezi M, Larionov AN (2010) Protolith age and provenance of metasedimentary rocks in Variscan allochthon units: U/Pb SHRIMP zircon data from the Orlica-Śnieżnik Dome, West Sudetes. Geol Mag 147:416-433

Korytowski A, Doerr W, Żelaźniewicz A (1993) U-Pb dating of (meta)granitoids in the NW Sudetes (Poland) and their bearing on tectono-stratigraphic correlation. Terra Abstr 5(Suppl. 1):331-332

Kryza R, Pin C, Vielzeuf D (1996) High-pressure granulites from the Sudetes (south-west Poland): evidence of crustal subduction and collisional thickening in the Variscan Belt. J Metam Geol 14:531-546

Lange U, Bröcker M, Mezger K, Don J (2002) Geochemistry and RbSr geochronology of a ductile shear zone in the Orlica-Śnieżnik dome (West Sudetes, Poland). Int J Earth Sci 91:1005-1016

Lange U, Bröcker M, Armstrong R, Żelaźniewicz A, Trapp E, Mezger $\mathrm{K}$ (2005) The orthogneisses of the Orlica-Śnieżnik complex (West Sudetes, Poland): geochemical characteristics, the importance of pre-Variscan migmatization and constraints on the cooling history. J Geol Soc London 162:973-984

Linnemann U, Romer RL (2002) The Cadomian Orogeny in SaxoThuringia, Germany; geochemical and $\mathrm{Nd}-\mathrm{Sr}-\mathrm{Pb}$ isotopic characterization of marginal basins with constraints to geotectonic setting and provenance. Tectonophysics 352:33-64

Linnemann U, Gehmlich M, Tichomirowa M, Buschmann B, Nasdala L, Jonas P, Lutzner H, Bombach K (2000) From Cadomian subduction to Early Palaeozoic rifting: the evolution of Saxo-Thuringia at the margin of Gondwana in the light of single zircon geochronology and basin development (Central European Variscides, Germany). Geol Soc London Spec Publ 179: 131-153

Linnemann U, McNaughton NJ, Romer RL, Gehmlich M, Drost K, Tonk C (2004) West African provenance for Saxo-Thuringia (Bohemian Massif); Did Armorica ever leave pre-Pangean Gondwana? U/Pb-SHRIMP zircon evidence and the Nd-isotopic record. Int J Earth Sci 93:683-705

Linnemann U, Gerdes A, Drost K, Buschmann B (2007) The continuum between Cadomian orogenesis and opening of the Rheic Ocean: Constraints from LA-ICP-MS U-Pb zircon dating and analysis of plate-tectonic setting (Saxo-Thuringian zone, northeastern Bohemian Massif, Germany). Geol Soc Am Spec Pap 423: The Evolution of the Rheic Ocean: From Avalonian-Cadomian Active Margin to Alleghenian-Variscan Collision 423: 61-96

Linnemann U, Pereira F, Jeffries TE, Drost K, Gerdes A (2008) The Cadomian Orogeny and the opening of the Rheic Ocean; the diacrony of geotectonic processes constrained by LA-ICP-MS U/Pb zircon dating (Ossa-Morena and Saxo-Thuringian zones, Iberian and Bohemian massifs). Tectonophysics 461:21-43

Lopez de Luchi MG, Cerredo ME, Siegesmund S, Steenken A, Wemmer K (2003) Provenance and tectonic setting of the protoliths of the metamorphic complexes of Sierra de San Luis. Rev Asoc Geol Argent 58:525-540

Martinez SS, Arenas R, Fernandez-Suarez J, Jeffries TE (2009) From Rodinia to Pangaea: ophiolites from NW Iberia as witness for a long-lived continental margin. Geol Soc London Spec Publ 327: 317-341

Matte P (1991) Accretionary history and crustal evolution of the Variscan belt in Western Europe. Tectonophysics 196:309-337

Mazur S, Aleksandrowski P, Szczepański J (2005) The presumed Teplá-Barrandian/Moldanubian Terrane boundary in the Orlica Mountains (Sudetes, Bohemian Massif); structural and petrological characteristics. Lithos 82:85-112

Mazur S, Szczepański J, Turniak K, McNaughton NJ (2012) Location of the Rheic suture in the eastern Bohemian Massif: evidence from detrital zircon data. Terra Nova 24:199-206

Mazur S, Turniak K, Szczepański J, McNaughton NJ (2013) Vestiges of Saxothuringian crust in the Central Sudetes, Bohemian Massif: 
zircon evidence of a recycled subducted slab provenance. Gondwana Res. http://dx.doi.org/10.1016/j.gr.2013.11.005

McLennan SM (1989) Rare earth elements in sedimentary rocks; influence of provenance and sedimentary processes. Rev Miner Geochem 21:169-200

McLennan SM, Taylor SR (1980) Th and U in sedimentary rocks; crustal evolution and sedimentary recycling. Nature 285:621-624

McLennan SM, Taylor SR (1991) Sedimentary rocks and crustal evolution; tectonic setting and secular trends. J Geol 99:1-21

McLennan SM, Taylor SR, McCulloch MT, Maynard JB (1990) Geochemical and $\mathrm{Nd}-\mathrm{Sr}$ isotopic composition of deep-sea turbidites; crustal evolution and plate tectonic associations. Geochim Cosmochim Acta 54:2015-2050

McLennan SM, Hemming S, McDaniel DK, Hanson GN (1993) Geochemical approaches to sedimentation, provenance, and tectonics. Geol Soc An Spec Pap 284:21-40

Murphy JB, Gutierrez-Alonso G, Nance RD, Fernandez-Suarez J, Keppie JD, Quesada C, Dostal J, Braid JA (2009) Rheic Ocean mafic complexes: overview and synthesis. Geol Soc London Spec Publ 327: 343-369

Murtezi M (2006) The acid metavolcanic rocks of the Orlica-Śnieżnik Dome (Sudetes): their origin and tectono-metamorphic evolution. Geol Sudet 38:1-38

Murtezi M, Fanning M (2005) The acid metavolcanic rocks of the Orlica-Śnieżnik Dome (Sudetes): their origin and tectono-metamorphic evolution. Geolines 38:19-20

Nance RD, Murphy JB, Strachan RA, Keppie JD, Gutierrez-Alonso G, Fernandez-Suarez J, Quesada C, Linnemann U, D'lemos RS Sergei A, Pisarevsky SA (2008) Neoproterozoic-early Palaeozoic tectonostratigraphy and palaeogeography of the peri-Gondwanan terranes: Amazonian v. West African connections. In: The boundaries of the West African Craton (N Ennih and JP Liégeois, eds). Geol Soc London Spec Publ 297: 345- 383

Nance RD, Gutiérrez-Alonso G, Keppie JD, Linnemann U, Murphy JB, Quesada C, Strachan RA, Woodcock NH (2010) Evolution of the Rheic Ocean. Gondwana Res 17:194-222

Nesbitt HW, Young GM (1982) Early Proterozoic climates and plate motions inferred from major element chemistry of lutites. Nature 299:715-717

Nesbitt HW, Young GM (1984) Prediction of some weathering trends of plutonic and volcanic rocks based on thermodynamic and kinetic considerations. Geochim Cosmochim Acta 48:1523-1534

Nesbitt HW, Young GM (1989) Formation and diagenesis of weathering profiles. J Geol 97:129-147

Opletal M, Domečka K (1983) Přehledná geologická mapa Orlických hor 1:100 000. Český Geol Úřad, Ústr Ústav Geol Praha

Patočka F, Storch P (2004) Evolution of geochemistry and depositional settings of early Palaeozoic siliciclastics of the Barrandian; Teplá-Barrandian Unit, Bohemian Massif, Czech Republic. Int J Earth Sci 93:728-741

Pereira MF, Chichorro M, Linnemann U, Eguiluz L, Silva JB (2006) Inherited arc signature in Ediacaran and Early Cambrian basins of the Ossa-Morena Zone (Iberian Massif, Portugal); paleogeographic link with European and North African Cadomian correlatives. Precambrian Res 144:297-315

Potter PE (1978) Petrology and chemistry of modern big river sands. J Geol 86:423-449

Roser BP, Korsch RJ (1988) Provenance signatures of sandstonemudstone suites determined using discriminant function analysis of major-element data. Chem Geol 67:119-139
Sánchez-García T, Quesada C, Bellido F, Dunning GR, González del Tánago J (2008) Two-step magma flooding of the upper crust during rifting: the early Paleozoic of the Ossa Morena Zone (SW Iberia). Tectonophysics 461:72-90

Skrzypek E, Schulmann K, Štípská P, Chopin C, Lehmann J, Lexa O, Haloda J (2011a) Tectono-metamorphic history recorded in garnet porphyroblasts: insights from thermodynamic modelling and electron backscatter diffraction analysis of inclusion trails. J Metam Geol 29:473-496

Skrzypek E, Štipská P, Schulmann K, Lexa O, Lexova M (2011b) Prograde and retrograde metamorphic fabrics-a key for understanding burial and exhumation in orogens (Bohemian Massif). J Metam Geol 29:451-472

Spadea P, Tortorici L, Lanzafame G (1980) VIth ophiolite field conference, Italy; field excursion guidebook. Gruppo Lavoro Ofioliti Mediterranee

Štípská P, Schulmann K, Kröner A (2004) Vertical extrusion and middle crustal spreading of omphacite granulite: a model of synconvergent exhumation (Bohemian Massif, Czech Republic). J Metam Geol 22:179-198

Sun SS, McDonough WF (1989) Chemical and isotopic systematics of oceanic basalts; implications for mantle composition and processes. Geol Soc London Spec Publ 42: 313-345

Szczepański J (2010a) Proweniencja i ewolucja tektonometamorficzna serii suprakrustalnej w krystaliniku Gór Bystrzyckich. Provenance and tectonometamorphic evolution of the supracrustal series from the Bystrzyckie Mts. Crystalline Massif. Wrocławska Drukarnia Naukowa PAN, Wrocław

Szczepański J (2010b) Geological setting of the Bystrzyckie Mts Crystalline Massif. Mineralogia - Special Papers 37: 140-144

Taylor SR, McLennan SM (1985) The continental crust; its composition and evolution; an examination of the geochemical record preserved in sedimentary rocks. Publ, Blackwell Sci

Taylor SR, McLennan SM (1995) The geochemical evolution of the continental crust. Rev Geophys 33:241-265

Turniak K, Mazur S, Wysoczański R (2000) SHRIMP zircon geochronology and geochemistry of the Orlica-Śnieżnik gneisses (Variscan belt of Central Europe) and their tectonic implications. Geodinam Acta 13:293-312

Valloni R, Maynard JB (1981) Detrital modes of Recent deep-sea sands and their relation to tectonic setting; a first approximation. Sedimentology 28:75-83

Xu Deru Gu, Xuexiang Li Pengchun, Chen Guanghao XB, Bachlinski R, He Zhuanli FG (2007) Mesoproterozoic-Neoproterozoic transition; geochemistry, provenance and tectonic setting of clastic sedimentary rocks on the SE margin of the Yangtze Block, South China. J Asian Earth Sci 29:637-650

Yang H (1998) Geochemical and Nd isotopic compositions of the metasedimentary rocks in the La Ronge Domain, Trans-Hudson Orogen, Canada: implications for evolution of the domain. Precambrian Res 92:37-64

Żelaźniewicz A, Dörr W, Bylina P, Franke W, Haack U, Heinisch H, Schastok J, Grandmontagne K, Kulicki C (2004) The eastern continuation of the Cadomian orogen: $\mathrm{U}-\mathrm{Pb}$ zircon evidence from Saxo-Thuringian granitoids in south-western Poland and the northern Czech Republic. Int J Earth Sci 93:773-781 